\title{
New data on the chronology of the Vale do Forno sedimentary sequence (Lower Tejo River terrace staircase) and its relevance as a fluvial archive of the Middle Pleistocene in western Iberia
}

\author{
Pedro P. Cunha ${ }^{\text {a, }}$, António A. Martins ${ }^{\text {b }}$, Jan-Pieter Buylaert ${ }^{c, d}$, Andrew S. Murray ${ }^{\mathrm{d}}$, \\ Luis Raposo ${ }^{\mathrm{e}}$, Paolo Mozzi ${ }^{\mathrm{f}}$, Martin Stokes ${ }^{\mathrm{g}}$ \\ ${ }^{a}$ MARE - Marine and Environmental Sciences Centre, Department of Earth Sciences, Universidade de Coimbra, Rua Sílvio Lima, Univ. Coimbra - Pólo II, \\ 3030-790, Coimbra, Portugal \\ b Instituto de Ciências da Terra (ICT), Departamento de Geociências, Universidade de Évora, Colégio Luís António Verney, Rua Romão Ramalho, 59, 7000- \\ 671, Évora, Portugal \\ ${ }^{c}$ Centre for Nuclear Technologies, Technical University of Denmark, Risø Campus, Denmark \\ d Nordic Laboratory for Luminescence Dating, Aarhus University, Risø DTU, Denmark \\ e Museu Nacional de Arqueologia, Praça do Império, 1400-206, Lisboa, Portugal \\ ${ }^{\mathrm{f}}$ Department of Geosciences, University of Padova, 35121, Padova, Italy \\ ${ }^{g}$ School of Geography, Earth and Environmental Sciences, University of Plymouth, Plymouth, Devon, PL4 8AA, UK
}

\section{A R T I C L E I N F O}

\section{Article history:}

Received 13 April 2016

Received in revised form

15 October 2016

Accepted 1 November 2016

Available online $\mathrm{xxx}$

\section{Keywords:}

Palaeolithic

Acheulean

Middle Pleistocene

Geomorphology

Luminescence dating

Fluvial terraces

River Tejo

Iberia

\begin{abstract}
A B S T R A C T
The Vale do Forno archaeological sites (Alpiarça, central Portugal) document the earliest human occupation in the Lower Tejo River, well established in geomorphological and environmental terms, within the Middle Pleistocene. In a staircase of six fluvial terraces, the Palaeolithic sites were found on the T4 terrace ( $+24 \mathrm{~m}$, above river bed) which is made of a basal Lower Gravels unit (LG) and an overlying Upper Sands unit (US). Geomorphological mapping, coupled with lithostratigraphy, sedimentology and luminescence dating (quartz-OSL and K-feldspar post-IRIR ${ }_{290}$ ) were used in this study. The oldest artefacts found in the LG unit show crude bifacial forms that can be attributed to the Acheulian. In contrast, the US unit has archaeological sites stratigraphically documenting successive phases of an evolved Acheulian. Luminescence dating and correlation with the Marine Isotopic Stages suggest that the LG unit has a probable age of ca. 335 to $325 \mathrm{ka}$ and the US unit an age of ca. 325 to $155 \mathrm{ka}$. This is in contrast to previous interpretations ascribing this terrace (and lithic industries) to the Last Interglacial and early phases of the Last Glacial. The VF3 site (Milharós), containing Micoquian (Final Acheulian) industries (with fine and elaborated bifaces), found in a stratigraphic level located between the T4 terrace deposits and a colluvium associated with Late Pleistocene aeolian sands, is younger than 155 ka but much older than $32 \mathrm{ka}$.
\end{abstract}

() 2016 Elsevier Ltd. All rights reserved.

\section{Introduction}

Understanding of the Palaeolithic occupation of Northern Europe has been substantially based on evidence from rivers (e.g. Bridgland et al., 2006). For Western Europe and specifically in Iberia, insights into the Palaeolithic occupation is similarly derived from its major rivers (from north to south: Douro, Tejo/Tagus,

\footnotetext{
* Corresponding author.

E-mail addresses: pcunha@dct.uc.pt (P.P. Cunha), aam@uevora.pt (A.A. Martins), jabu@dtu.dk (J.-P. Buylaert), anmu@dtu.dk (A.S. Murray), 3raposos@sapo.pt (L. Raposo), paolo.mozzi@unipd.it (P. Mozzi), m.stokes@plymouth.ac.uk (M. Stokes).
}

Guadiana, Guadalquivir) (e.g. Santonja and Villa, 2006). Within this context, the Vale do Forno archaeological sites (Alpiarça, in central Portugal; Fig. 1) provide the earliest and most well documented human occupation in the Lower Tejo (the Portuguese part of the Tejo basin). Lower Palaeolithic bifacial sites are common, often well represented by lithic industries. Their local stratigraphy and technological characteristics indicate successive phases of what is commonly named as the Acheulian. However, they were chronologically poorly constrained.

From the Spanish border to the Atlantic coast, the Tejo crosses major faults which provide a natural geomorphological subdivision of the river into a series of valley reaches (I to V; Cunha et al., 2005).

http://dx.doi.org/10.1016/j.quascirev.2016.11.001

0277-3791/@ 2016 Elsevier Ltd. All rights reserved. 


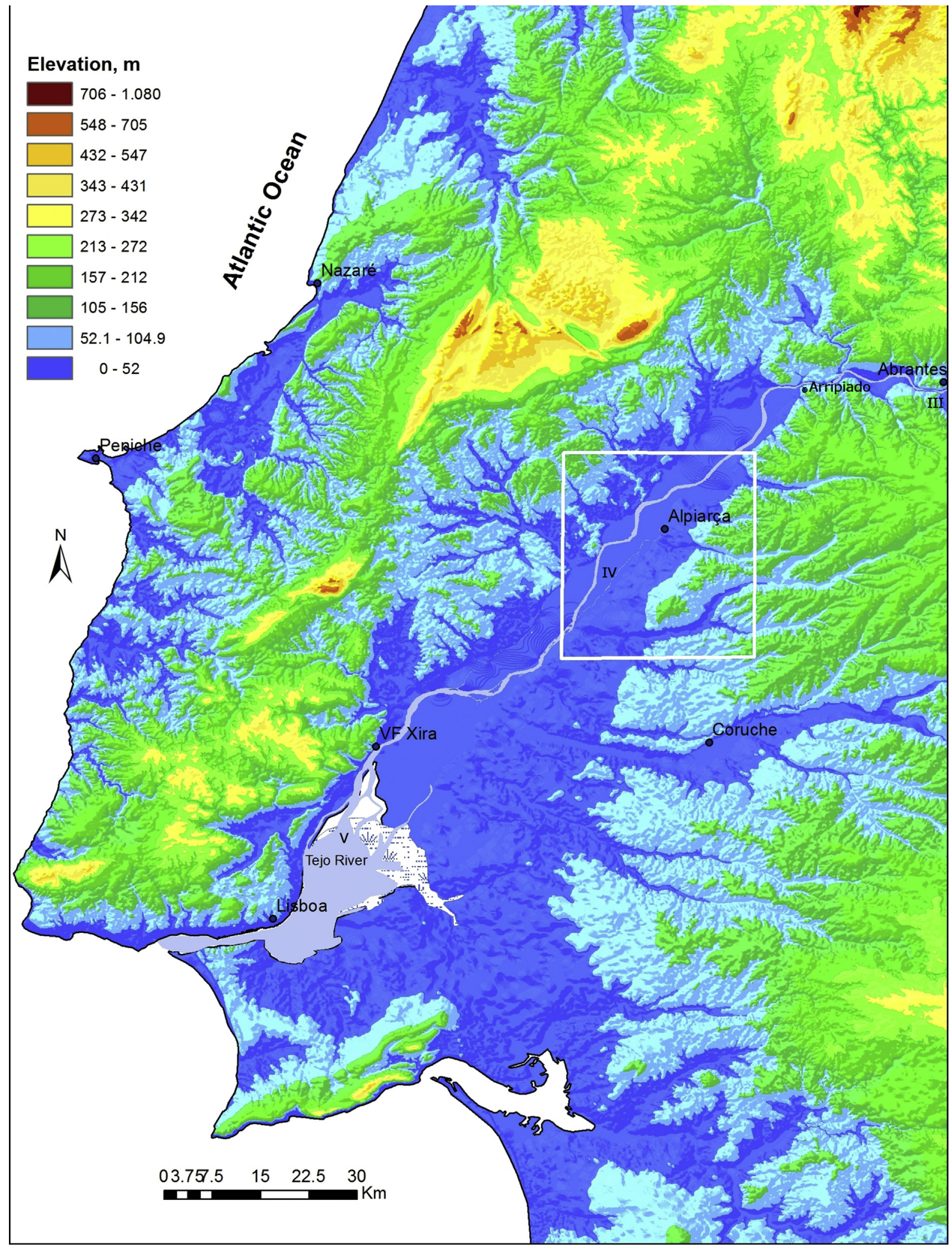

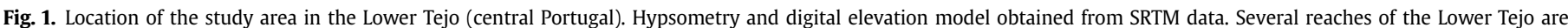

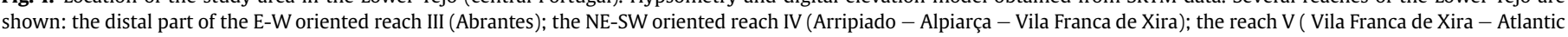
coast; the modern estuary). 
In Reach I, within the Ródão and Arneiro depressions, the Tejo has cut well-developed staircases of alluvial terraces (Cunha et al. 2008, 2012), built on a sedimentary bedrock of the Lower Tejo Cenozoic Basin (LTCB; e.g. Pais et al., 2012). Here, the Tejo also flows across a series of highly resistant quartzite ridges. In Reach II, the Tejo flows over Paleozoic basement through a NE-SW orientated valley for some $30 \mathrm{~km}$ along which terraces are largely absent. In reach III, the Tejo is routed $\mathrm{E}-\mathrm{W}$, crossing three structural depressions with a Tertiary cover (Martins et al., 2009). In reach IV, the Tejo changes to a NNE-SSW trend, with valley sides displaying different degrees of terrace staircase development (Martins et al., 2010a, 2010b) (Figs. 1 and 2). Reach V corresponds to the Tejo estuary which covers a wide area but its final connection to the Atlantic is through a gorge. Here, terraces are not well described. Throughout the Lower Tejo region the best developed terraces, sometimes forming up to six levels, are typically associated with areas of weaker bedrock (e.g. Tertiary sediments in reaches I, III and IV) where the river has been able to enlarge the valley.

The study area is located on the left flank of the middle part of a $\sim 85 \mathrm{~km}$ long NNE-SSW orientated valley-section of reach IV, some $\sim 100 \mathrm{~km}$ from the river mouth. The geomorphological characteristics of this reach are quite different from the Lower Tejo upstream (reaches I, II and III). In reach IV, the Tejo has a wide alluvial plain (up to $10 \mathrm{~km}$ wide) with an extensive staircase of six fluvial terraces (T1 to T6) developed along its valley sides (Martins, 1999). Here, the modern Tejo can be considered a low sinuosity, single-channel river with large sand bars, and its alluvial plain connects with a tidedominated estuary.

The NNE-SSW oriented valley of reach IV is controlled by the NNE-SSW Lower Tejo Valley fault zone (e.g. Choffat, 1907; Bensaúde, 1910; Freire de Andrade, 1933; Cabral et al., 2003, 2004, 2013; Cabral and Ribeiro, 1988, 1989; Cabral, 1995, 2012; Vilanova and Fonseca, 2004; Carvalho et al., 2008, 2014; Martins et al., 2009; Besana-Ostman et al., 2012). This is expressed as a regional scale tectonic lineament concealed by Holocene sediments. This valley is developed in a low uplift area $(<100 \mathrm{~m}$ during the last ca. $2 \mathrm{Ma}$ ) with some subsidence in the present estuary (reach V). The interplay between these regional tectonic characteristics and Pleistocene to Holocene glacio-eustatic sea-level changes has strongly influenced the formation of fluvial terraces and sedimentary valley-fill (eg. Merritts et al., 1994; Blum and Törnqvist, 2000). The high amplitude sea-level changes that characterized the Middle and Late Pleistocene controlled the episodic down-cutting phases of the river during sea-level lowstands; these alternated with flooding and agradation phases in the incised valley during highstands (Cunha et al., 2016). Such climate related eustatic oscillations are superimposed onto a long-term uplift pattern, both phenomena having controlled the river terrace staircase development (Cunha et al., 2005, 2008; Martins et al., 2010a, 2010b).

In reach IV, several archaeological studies have been undertaken in the last 70 years (e.g. Breuil and Zbyszewski, 1942, 1945; Zbyszewski, 1946; Raposo, 1995a, 1995b; Mozzi et al., 2000). The prehistoric human occupation of this area is of renewed interest because it contains evidence for an extensive Palaeolithic occupation. Related archaeological sites are present on both sides of the river, from the Lisboa area to the vicinity of Torres Novas (Fig. 2). The site of Santo Antão do Tojal (near the estuary) is considered especially important, because dated fossil remains of Palaeoloxodon antiquus and Equus caballus were found in association with lithic industries (Zbyszewski, 1943, 1977; Raposo, 1995a). The study of these sites has brought new insights into the technology and the typology of the Lower and Middle Palaeolithic. Further new insights have been achieved by combining archaeological, geomorphological and lithostratigraphic studies. A chronological framework for the lithic industries found in these sites has been attempted, based on their stratigraphic position in the terrace deposits and by thermoluminescence (TL) dating (Mozzi et al., 2000). However, these TL dates from the Vale do Forno area were minimum age estimations. Furthermore, the validity/accuracy of these TL ages was unclear because of a lack of geochronological dating from other archaeological sites within reach IV (e.g. Raposo and Cardoso, 1998).

The main aim of this paper is to develop a new chronostratigraphy for the sedimentary succession of the Lower Tejo terrace T4 in the Vale do Forno area. A new and more robust chronologic framework will allows us to provide better dating of the Palaeolithic industries found here in situ and to estimate the duration of aggradation and down-cutting phases associated with this terrace. It will also allow correlation of these phases with extrinsic fluvial controls (climate, glacio-eustatic sea-level changes and tectonics). Finally, integration of the terrace sedimentology with an improved chronostratigraphic framework will allow a revised assessment of the palaeo-environmental conditions affecting this region of western Iberia during the Middle Pleistocene.

\section{Geological setting}

The study area mainly comprises siliciclastic sediments of the Lower Tejo Cenozoic Basin (LTCB), dominated by Miocene sediments on the western side and Pliocene sediments on the eastern side of the valley (Fig. 2). Eocene to Oligocene continental sediments outcrop along the western margin of the LTCB, forming a narrow fringe along a thrust fault contact with Mesozoic limestones. The Neogene succession is composed of fluvial gravels, sands and silty clays, but also lacustrine/palustrine carbonates (Barbosa, 1995). Pleistocene sediments are represented by fluvial terraces, an aeolian cover unit (Carregueira Formation) and colluvium (e.g. Martins et al., 2009, 2010a, 2010b). Holocene sediments form an extensive alluvial plain, ca. $5 \mathrm{~km}$ wide at Alpiarça and up to $10 \mathrm{~km}$ wide in the downstream part of the study area. In reach IV, a deeply incised valley was excavated during the Marine Isotopic Stage (MIS) 2 sea-level fall, between 30,000 and 20,000 yrs ago; valley infilling occurred due to a combination of sea-level rise (20,000 to 7000 yrs ago) and an increase in sediment supply, resulting from climate change and human impact (Van der Schriek et al., 2007; Vis et al., 2008, 2016; Vis, 2009).

\section{Previous studies}

Previous studies in reach IV by Breuil and Zbyszewski (1942) and Zbyszewski $(1943,1946)$ identified only four fluvial terraces. These were represented in the 1/50,000 geologic maps using a stratigraphic framework based on the heights of terrace surfaces above river bed (a.r.b.): Q1 as +75-95 m; Q2 as +50-65 m; Q3 as $+25-40 \mathrm{~m}$ and $\mathrm{Q} 4$ as $+8-15 \mathrm{~m}$. A glacio-eustatic model, based on the European Alpine glaciations, was used to explain the terrace formation as well as to provide a relative chronology. Q1 and Q2, the "upper terraces", were considered to relate to the Gunz-Mindel interglacial, or even to the pre-Gunz (Q1). Q3, the "middle terrace", was related to the late Mindel and the earliest Riss and Q4 (the "lower terrace") was ascribed to the Riss-Würm interglacial.

In more recent years the terrace stratigraphy in reach IV has been revised and now comprises six terrace levels ( $\mathrm{T} 1$ is the uppermost and the T6 the lowermost; Corral, 1998a, 1998b; Martins, 1999; Rosina, 2002; Cunha et al., 2008; Martins et al., 2009, 2010a, 2010b). The additional terraces were recognized within the highest and lowest parts of the landscape, the new highest terrace occurring above the original Q1 level and the new lowest terrace occurring below the old Q4 level. Thus, the old Q1, Q2, Q3 and Q4 stratigraphy has now been reclassified as the T2, T3, T4 and T5 terrace levels. 


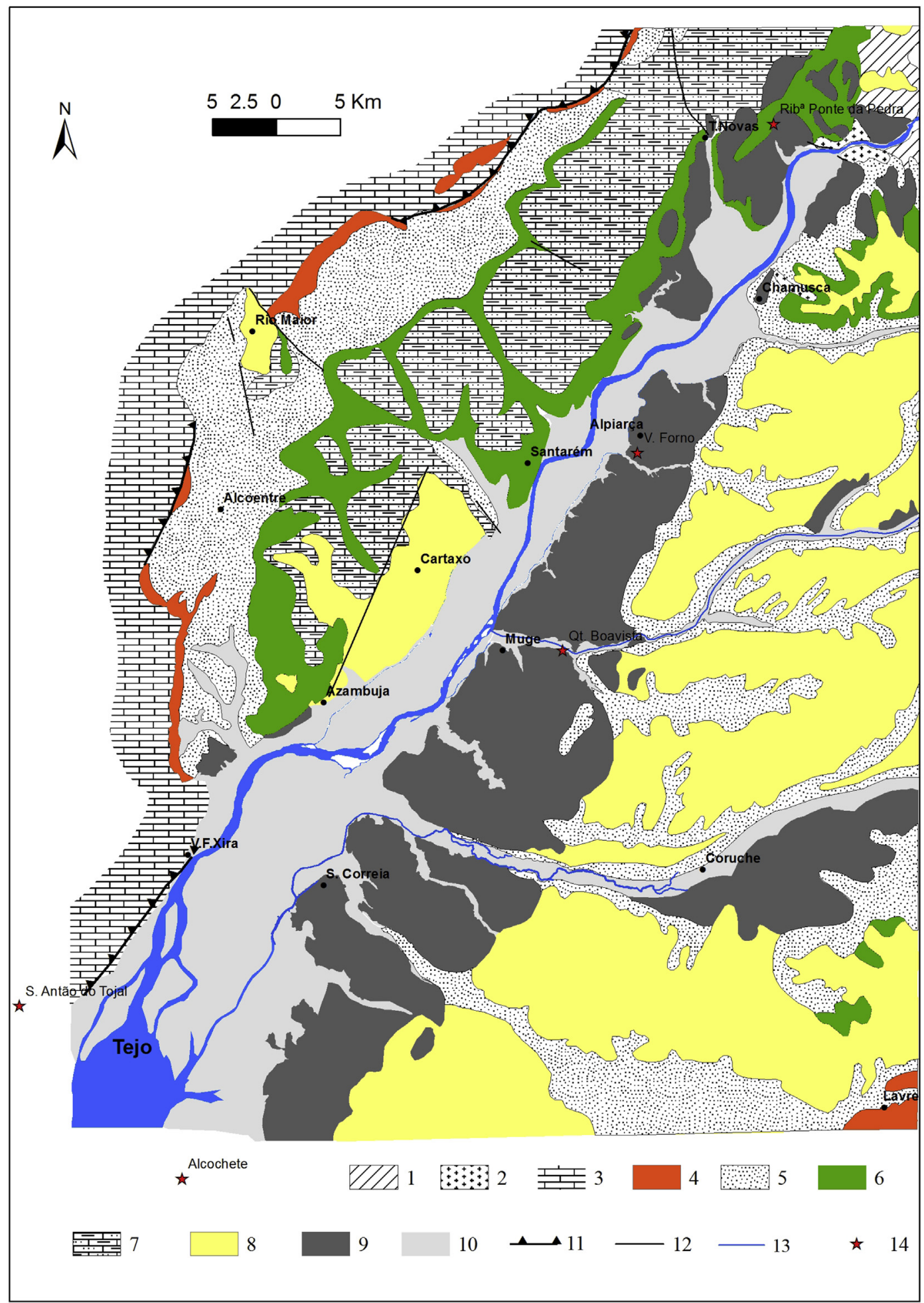

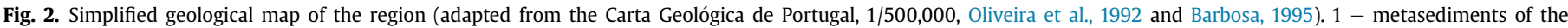

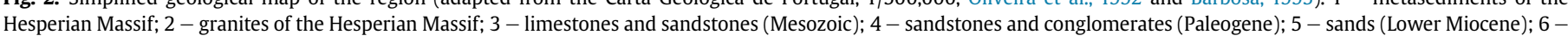

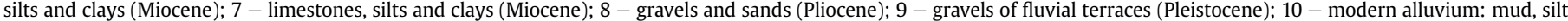
and sand (Holocene); 11 - thrust fault; 12 - fault; 13 - stream; 14 - archaeological site.

In the study area, two lithostratigraphic units were identified within the T4 terrace (Mozzi et al., 2000): a "Lower Gravels unit" (LG) and an "Upper Sands unit" (US), which are locally separated by a disconformity. The LG unit was linked to glacial conditions and a sea-level lowstand, whereas the US unit was linked to an interglacial period of high sea level.

No pre-bifacial (pre-Acheulian) assemblages have been found at the Vale do Forno archaeological sites or elsewhere in the Lower 
Tejo basin. The scarce lithic tools that were found in the LG unit comprise crude bifacial forms attributed to an "Early Acheulian" (Zbyszewski, 1946), but they are not sufficiently representative as to be ascribed to any specific Acheulian evolutionary phase. In the US unit, prolific industries represented by a dozen sites have been registered since the 1940s, especially at Vale do Forno (VF) (Breuil and Zbyszewski, 1942; Zbyszewski, 1946; Raposo et al., 1985; Mozzi et al., 2000; Raposo, 2002). One such example is the VF1 site, comprising a classic bifacial industry within a thin gravel bed stratigraphically located in a lower sector of the US unit. The VF8 site is located in a stratigraphically higher position and contains an industry dominated by small to medium sized flake tools, but with some rare bifaces or biface-like tools. Finally, another relevant industry has been found at site VF3, on a thin gravel bed located between a sandy silt level at the top of the T4 terrace and an overlying aeolian-colluvial deposit. The VF3 industry, has traditionally been labelled as Micoquian and considered to represent the very end of the Acheulian complex (Raposo et al., 1985).

For the Acheulian industries that have been recorded in the Upper Sands unit, Raposo (1995a) and Mozzi et al. (2000) proposed an age of ca. 150 to $70 \mathrm{ka}$, corresponding to the last interglacial/ early phases of the last glacial (MIS 5 and the end of MIS 6). This is considerably younger than the age proposed by the previous studies, which linked the T4 terrace to the late Mindel and early Riss (ca. 400 to $300 \mathrm{ka}$ ). The younger chronology was based upon three arguments:

a) The occurrence of Micoquian industries at the VF3 site; these are extremely evolved, both from the technological and typological point of view;

b) The palaeoenvironmental interpretation of a spatially extensive floodplain succession with palaeosols and grey clays containing temperate floral fossils located below the upper Acheulian horizons. These fine-grained deposits were thought likely to indicate the Eemian transgressive episode;

c) The thermoluminescence (TL) dates obtained from the VF8 sequence. These provided minimum ages for three stratigraphic levels of the US: $117 \mathrm{ka}$ ( $-26 \mathrm{ka}+$ infinite), $119 \mathrm{ka}(-32$ ka + infinite) and >124 ka (Raposo, 1995a; Mozzi et al., 2000).

Correlations by Martins et al. (2010b) and Cunha et al. (2012), based mainly on geomorphologic criteria and new luminescence dating, indicated that the terrace containing the Lower Palaeolithic industries at Vale do Forno is equivalent to the T4 terrace of the upstream reach III (at Abrantes) and reach I (at Ródão) of the Lower Tejo. In these reaches, finite infrared stimulated luminescence (IRSL, from K-feldspar) and optically stimulated luminescence (OSL, from quartz) ages were obtained for the T4, T5 and T6 terrace deposits (Cunha et al., 2008, 2012; Martins et al., 2010a, 2010b): T4 ca. 280 to $136 \mathrm{ka}$; T5 - ca. 136 to $75 \mathrm{ka}$; T6 - 62 to $32 \mathrm{ka}$. Thus the OSL ages for the $\mathrm{T} 4$ obtained in the upstream reaches can be used to constrain the age of the Vale do Forno industries. However, this time range should be regarded as a first estimate, since the ages of the T4 terrace were obtained using the conventional lowtemperature $\left(50{ }^{\circ} \mathrm{C}\right)$ IRSL signal method, for which the fading correction used (Lamothe et al., 2003) is not completely appropriate. This resulted in a significant underestimation for the oldest samples (Cunha et al., 2008; Martins et al., 2009, 2010a, 2010b). Because of this age underestimation issue, Cunha et al. (2012) proposed that the T4 aggradation should probably range in age from $340 \mathrm{ka}$ to $160 \mathrm{ka}$. In the present study, these limitations in luminescence dating are largely overcome by a new protocol that uses the elevated-temperature post-IRIR stimulation (Thomsen et al., 2008; Buylaert et al., 2009) for measuring samples that have the quartz-OSL signal in saturation. The pIRIR $_{290}$ dating method, using K-feldspar as the dosimeter, has negligible fading and can yield accurate results back to 600 ka (Buylaert et al., 2012).

\section{Materials and methods}

The information presented here is derived from geomorphological, stratigraphical, sedimentological and chronological data using a standard approach (e.g. Stokes et al., 2012): (1) a geomorphological study of the region, complemented by local detailed investigations and the generation of detailed maps using GIS, (2) field descriptions and stratigraphic correlation of the sedimentary units, (3) sedimentological characterization of the deposits and (4) luminescence dating.

Geomorphological mapping was undertaken in three stages: (1) field mapping onto topographical $(1 / 25,000)$ and geological (1/ 50,000 ) base maps; (2) analysis of $1 / 25,000$ black/white aerial photographs and of a digital elevation model (DEM) based upon a $1 / 25,000$ topographic database; and (3) field ground truthing.

The T4 terrace deposits associated with the Vale do Forno archaeological sites and that of the equivalent alluvial sequence in the adjacent Vale de Atela sector were also studied in detail in order to improve our understanding of the local stratigraphy. Field work included stratigraphic logging and sedimentological characterization of the sedimentary deposits in order to obtain data on the depositional facies, including the sediment colour, texture, maximum particle size, clast lithology, fossil content, bedding and its overall depositional architecture. Soil features and horizons were described in the field, following international guidelines (Jahn et al., 2006).

Samples for OSL dating were collected from several Pleistocene sedimentary units that outcrop in the study area, namely fluvial sands of the T4 and T5 terraces and aeolian sands of the Carregueira Formation. A large number of different stratigraphic levels within the $\mathrm{T} 4$ terrace (from the base to the top) were sampled in order to improve the chronology of the terrace sequence and its associated lithic industries.

OSL dating is an absolute dating technique that measures the time elapsed since sedimentary grains of quartz or feldspar were last exposed to daylight (Duller, 2004). Exposure to daylight during sediment transport removes the latent luminescence signal from the quartz or feldspar crystals. After burial, the luminescence signal (trapped charge) starts to accumulate in the mineral grains due to ionising radiation arising from the decay of ${ }^{238} \mathrm{U},{ }^{232} \mathrm{Th}$ and ${ }^{40} \mathrm{~K}$ present in the sediment itself and from cosmic ray bombardment. In the laboratory, the equivalent dose $\left(D_{e}\right.$, assumed to be the dose absorbed since last light exposure, i.e. the burial dose, expressed in $\mathrm{Gy}$ ) is determined by comparing the natural luminescence signal resulting from charge trapped during burial with that trapped during a laboratory irradiation. Dividing the $\mathrm{D}_{\mathrm{e}}$ by the environmental dose rate (in $\mathrm{Gy} / \mathrm{ka}$ ) gives the luminescence age of the sediment. Environmental dose rates are calculated from the radionuclide concentrations $(\mathrm{U}, \mathrm{Th}, \mathrm{K})$ of the sediment. In this study, the radionuclide concentrations were measured by highresolution gamma spectrometry (Murray et al., 1987). These concentrations were then converted to environmental dose rates using the conversion factors given by Olley et al. (1996). For the calculation of the dose rate of sand-sized K-feldspar grains an internal $\mathrm{K}$ content of $12.5 \pm 0.5 \%$ was assumed (Huntley and Baril, 1997). Sampling tubes were hammered into previously cleaned outcrops. Immediately adjacent to each tube, a sub-sample of sediment was collected for determination of field water content, saturation water content and dose rate.

Sample preparation for luminescence analyses was done in darkroom conditions. Samples were wet-sieved to separate the $180-250 \mu \mathrm{m}$ grain size fraction followed by $\mathrm{HCl}(10 \%)$ and $\mathrm{H}_{2} \mathrm{O}_{2}$ 
(10\%) treatments to remove carbonates and organic matter, respectively. The K-feldspar-rich fraction was floated off using a heavy liquid solution of sodium polytungstate $\left(\rho=2.58 \mathrm{~g} / \mathrm{cm}^{3}\right)$. The quartz fraction was obtained by etching another portion with concentrated HF (40\%). The K-feldspar fraction was treated with $10 \% \mathrm{HF}$ for $40 \mathrm{~min}$ to remove the outer alpha-irradiated layer and to clean the grains. After etching, both the quartz and K-feldspar fractions were treated with $\mathrm{HCl}(10 \%)$ to dissolve any remaining fluorides. Quartz purity was confirmed by the absence of a significant infrared-stimulated luminescence (IRSL) signal.

Equivalent doses were measured on automated Risø TL/OSL DA20 readers, each containing a beta source calibrated for irradiation on stainless steel discs and cups. Quartz measurements were made on large $(8 \mathrm{~mm})$ aliquots containing several thousands of grains mounted on stainless steel discs. Small ( $2 \mathrm{~mm}$ ) aliquots of K-feldspar were mounted on stainless steel cups.

Quartz dose estimates were made using a standard SAR protocol using blue light stimulation at $125^{\circ} \mathrm{C}$ for 40 s with a $240{ }^{\circ} \mathrm{C}$ preheat for $10 \mathrm{~s}$, a $200{ }^{\circ} \mathrm{C}$ cut heat and an elevated temperature $\left(280{ }^{\circ} \mathrm{C}\right)$ blue-light stimulated clean-out step (Murray and Wintle, 2000, 2003). The OSL signal was detected through a U-340 filter. All samples have a strong fast component. The net OSL signal was calculated from the initial $0.0-0.8 \mathrm{~s}$ of stimulation and an early background between 0.8 and $1.6 \mathrm{~s}$.

The K-feldspar $D_{\mathrm{e}}$ estimates were measured with a post-IR IRSL SAR protocol using a blue filter combination (Thomsen et al., 2008; Buylaert et al., 2012). The preheat was $320^{\circ} \mathrm{C}$ for $60 \mathrm{~s}$ and the cutheat $310{ }^{\circ} \mathrm{C}$ for $60 \mathrm{~s}$. After preheating the aliquots were IR bleached at $50{ }^{\circ} \mathrm{C}$ for $200 \mathrm{~s}$ ( $\mathrm{IR}_{50}$ signal) and subsequently stimulated again with IR at $290{ }^{\circ} \mathrm{C}$ for $200 \mathrm{~s}$ (pIRIR 290 signal). It has been shown by Buylaert et al. (2012) that the post-IR IRSL signal measured at $290{ }^{\circ} \mathrm{C}$ can give accurate results without the need to correct for signal instability. For all IR $_{50}$ and pIRIR 290 calculations, the initial $2 \mathrm{~s}$ of the luminescence decay curve less a background derived from the last $50 \mathrm{~s}$ was used.

\section{Results}

\subsection{Terrace staircase}

In the study area, the culminant sedimentary surface (CSS) is the surface of the Serra de Almeirim Conglomerates (Barbosa, 1995). This uppermost sedimentary unit of the LTCB, and the upstream equivalent in Portugal, represented by the Falagueira Formation (Cunha, 1992, 1996), has been considered of latest Zanclean to Gelasian age (3.65-1.8 Ma; Cunha et al., 2012, 2016; Pais et al., 2012; Diniz et al., 2016). Previous studies (e.g. Cunha, 1992, 1996; Cunha et al., 1993; 2005, 2016) indicated that by ca. $3.65 \mathrm{Ma}$ (end of the Zanclean) the westward draining Atlantic fluvial drainage (in the Lower Tejo basin), during a period of high sea-level (up to $+40 \mathrm{~m}$ ), also received drainage from the previous endorheic Madrid Cenozoic basin (e.g. Pérez-González, 1994). Our interpretation considers a spill-over drainage model (e.g. Douglass and Schmeeckle, 2007) as responsible for the change of the Douro and Madrid Cenozoic basins from endorheic to exorheic: when the hot climate of the Pliocene became very humid, the large water level increase in each endorheic basin (forming a huge lake) induced an overspill towards the west, to the lower Atlantic Ocean.

Ongoing studies indicate that in the Lower Tejo Basin the incision stage began by 1.8 Ma (Cunha et al., 2012, 2016), controlled both by climate (global cooling; see, e.g., Bridgland and Westaway, 2014), eustasy (sea-level lowering) and tectonics (ongoing crustal uplift since 9.5 Ma due to Iberia-Africa convergence) (e.g. Cunha, 1992; Cunha et al., 1993; 2016; De Vicente et al., 2011). During the subsequent fluvial incision, the Lower Tejo and its tributaries developed a staircase of six terraces into the fill of the LTCB (Fig. 3). In the study area (from Azinhaga to Muge; Fig. 3), only five terraces are represented because the T6 terrace is buried by Holocene alluvium. The staircase can be characterized as follows (Table 1):

- The remnant surface of Serra de Almeirim conglomerates (CSS) is at ca. $133 \mathrm{~m}$ a.s.l. (+123 m, above river bed, a.r.b.) at Alpiarça; the unit has a thickness of ca. 35-40 m and consists of fluvial gravels interbedded with coarse sands;

- The T1 terrace is at ca. $115 \mathrm{~m}$ a.s.l. $(+107 \mathrm{~m})$ around Vale de Cavalos (upstream) and at ca. $90 \mathrm{~m}$ a.s.l. (+86 m) around Muge (downstream) (Fig. 3); T1 has a maximum thickness of ca. $5 \mathrm{~m}$, and is made up of reddish gravels overlying the Miocene substratum;

- T2 is represented by the terrace treads at 82 to $72 \mathrm{~m}$ a.s.l. ( +74 to $68 \mathrm{~m}$ ). The T2 is a 6-7 m-thick fill terrace, mainly composed of brown massive clast-supported gravels;

- T3 terrace is at 60 to $50 \mathrm{~m}$ a.s.l. ( +52 to $46 \mathrm{~m}$ ). It is well preserved on the north side of the Muge stream where it is ca. 10 m-thick; - T4 terrace is at 38 to $20 \mathrm{~m}$ a.s.l. ( +30 to $16 \mathrm{~m}$ ). It forms a $5 \mathrm{~km}$ long ramp, rising from 20 to $40 \mathrm{~m}$ a.s.l. north of the Muge stream; boreholes for water extraction and the available outcrops indicate that the T4 has a maximum thickness of ca. $30 \mathrm{~m}$ at Alpiarça (Mozzi et al., 2000) and ca. $23 \mathrm{~m}$ near Muge;

- T5 terrace forms a narrow strip at 13 to $10 \mathrm{~m}$ a.s.l. (+3 to $6 \mathrm{~m}$ ), between Vale de Cavalos and Muge; in the study area, the base of T5 is below the top of the modern alluvial plain but downstream of Muge, the whole T5 thickness is buried by the Holocene valley fill; boreholes indicate a thickness of 9-10 m;

- Boreholes indicate that the T6 terrace top is at $-4 \mathrm{~m}$ a.s.l. and is ca. 18 m-thick;

- A late Pleistocene aeolian sand unit (Carregueira Formation), usually $<3$ m-thick, locally covers the T5 and T4 terraces;

- Boreholes revealed a ca. 30 m-thick Holocene succession (Vis, 2009).

The lithostratigraphy of the T4 terrace was described by Mozzi et al. (2000) (Figs. 4-6). In the present study additional data were collected, with three stratigraphic logs being obtained from Vale do Forno and Vale de Atela (Fig. 7). Fig. 8 shows the sand-pit (27 $\mathrm{m}$ high) used to produce the Vale de Atela-E log (Fig. 7).

Outcrops of the LG unit show a minimum thickness of $10 \mathrm{~m}$, but the overall maximum thickness appears to be $13-15 \mathrm{~m}$ based upon water-well stratigraphy. The unit is made of subrounded to subangular gravels of quartzite (predominant) and quartz, with a coarse sandy matrix. The sediments usually occur as clastsupported imbricated gravels that display a crude horizontal bedding (lithofacies Gh), interpreted as longitudinal fluvial bars. Locally, some small channel geometries can be seen and lenses of other facies can be intercalated with the dominant $\mathrm{Gh}$. These include the lithofacies $\mathrm{Gp}$, characterized by gravel with planar cross-beds, interpreted as transverse fluvial bars, and lithofacies Sm, comprising massive medium sand, interpreted as deposited by turbulent fluvial currents. The LG unit deposits are interpreted as corresponding to a gravelly braided fluvial system, transporting a coarse bed load (average maximum pebble size of $14 \mathrm{~cm}$, but with rare boulders reaching $30 \mathrm{~cm}$ in diameter).

The US unit has a maximum thickness of $20 \mathrm{~m}$. The basal $2-4 \mathrm{~m}$ of the unit (Fig. 7) comprises either (1) massive and pebbly coarse sands (lithofacies Sc) or (2) trough cross-beds (lithofacies St). These represent bed-load transport of sand, mainly as sinuous-crested fluvial dune bedforms. The middle part of the US unit (ca. 6-10 m) consists of very thick (up to $5.5 \mathrm{~m}$ ) massive grey clayey silts (lithofacies Fm) that locally contain small fragments of coal. 


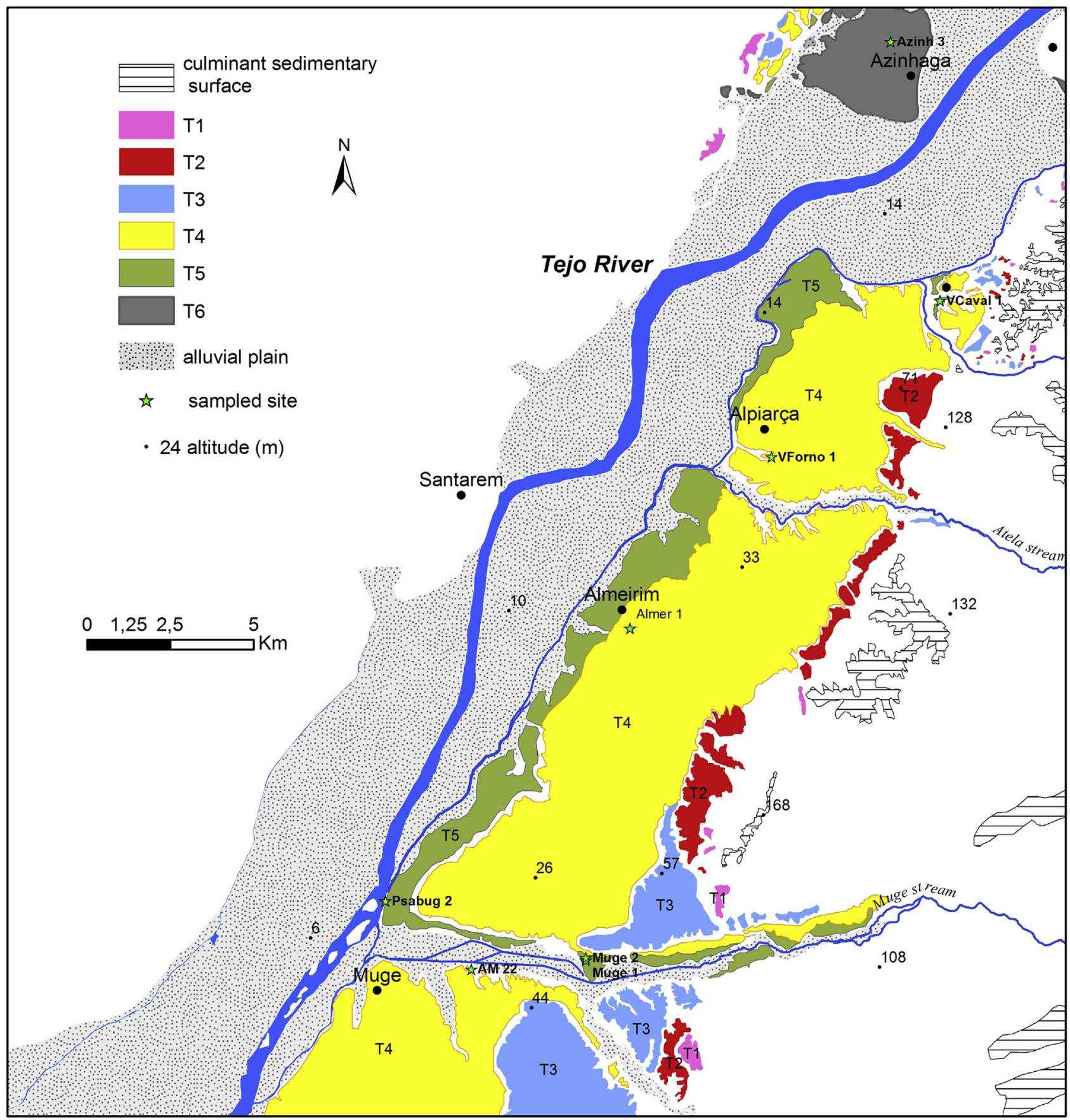

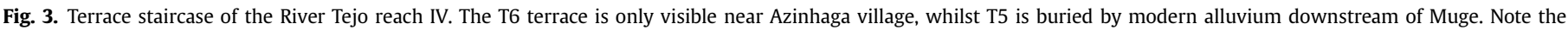
asymmetric development of the terraces between the two sides of Tejo valley downstream of Chamusca. Terraces are very scarce on the west side of the river valley.

The silts are intercalated with thin beds $(<1 \mathrm{~m})$ of massive medium to fine yellowish sands (lithofacies $\mathrm{Sm}$ ). Collectively, this alternation of silts and fine sands is interpreted as overbank deposits comprising crevasse splays ( $\mathrm{Sm}$ ) and backswamp deposits (Fm). Leaves of Salix and rhizomes of Nymphea (Zbyszewski, 1946) and a pollen content limited to Ericacea and Pinus (Montenegro de Andrade, 1944) have been reported in the backswamp deposits. The backswamp deposits document a marked decrease in fluvial energy and the formation of an extensive flood-plain adjacent to channel deposits to the west (Fig. 5). The upper part of the US unit (ca. 8-9 $\mathrm{m}$ ) is dominated by tabular beds (Fig. 8) of lithofacies Sc and $\mathrm{Sm}$, with rare thin intercalations of facies Fm. Thus, the upper part of the US unit indicates that the environment changed to a system dominated by sand flats and large bars.

The $<2 \mathrm{~mm}$ fraction of the US overbank deposits have a clay mineralogy of dominant montmorillonite/vermiculite in association with kaolinite and illite (Mozzi et al., 2000); a significant part of these clay minerals could be sourced from erosion of the local Neogene sedimentary units. Zbyszewski (1946) interpreted the US macrofloral assemblages to indicate a mild-temperate climate similar to that of the present day.

Palaeosols within the US unit provide some information regarding drainage and climate conditions. A trench (Fig. 9) excavated at location AL1 (see Fig. 4), records three separate palaeosols 
Table 1

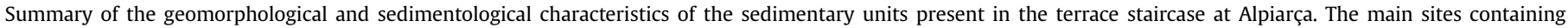
Palaeolithic industries located in the Lower Tejo reach IV are also listed. MPS - maximum clast size $(\mathrm{cm})$.

\begin{tabular}{|c|c|c|c|c|c|}
\hline $\begin{array}{l}\text { Geomorphic unit, } \\
\text { main site }\end{array}$ & $\begin{array}{l}\text { Elevation above } \\
\text { sea level and above } \\
\text { river bed }\end{array}$ & $\begin{array}{l}\text { Down-cutting from } \\
\text { the previous } \\
\text { geomorphic unit }\end{array}$ & $\begin{array}{l}\text { Thickness of } \\
\text { the associated } \\
\text { deposits }\end{array}$ & $\begin{array}{l}\text { Sedimentary characteristics of the associated } \\
\text { sedimentary deposits }\end{array}$ & $\begin{array}{l}\text { Main sites with lithic industries in } \\
\text { stratigraphy }\end{array}$ \\
\hline $\begin{array}{l}\text { Culminant surface of } \\
\text { the sedimentary } \\
\text { basin (CSS) }\end{array}$ & $\begin{array}{l}152 \mathrm{~m} \text { a.s.l. }+144 \mathrm{~m} \\
\text { (a.r.b.) }\end{array}$ & $0 \mathrm{~m}$ & $35-40 \mathrm{~m}$ & $\begin{array}{l}\text { Gravels with very coarse sands with through cross } \\
\text { lamination. Clasts of quarzite ( } 80 \%) \text { and quartz } \\
(20 \%) . \mathrm{MPS}=15 \mathrm{~cm}\end{array}$ & Not found \\
\hline T1 terrace & $\begin{array}{l}115 \mathrm{~m} \text { a.s.l. }+107 \mathrm{~m} \\
\text { (a.r.b.) }\end{array}$ & $42 \mathrm{~m}$ & $5 \mathrm{~m}$ & $\begin{array}{l}\text { Gravels with clasts of quarzite (76\%) and quartz } \\
\text { (26\%). MPS }=22 \mathrm{~cm}\end{array}$ & Not found \\
\hline T2 terrace & $\begin{array}{l}82 \mathrm{~m} \text { a.s.l. }+74 \mathrm{~m} \\
\text { (a.r.b.) }\end{array}$ & $40 \mathrm{~m}$ & $6-7 \mathrm{~m}$ & $\begin{array}{l}\text { Gravels with clasts of quarzite (69\%) and quartz } \\
\text { (31\%). MPS }=17 \mathrm{~cm}\end{array}$ & Not found \\
\hline T3 terrace & $\begin{array}{l}60 \mathrm{~m} \text { a.s.l. }+52 \mathrm{~m} \\
\text { (a.r.b.) }\end{array}$ & $32 \mathrm{~m}$ & $10 \mathrm{~m}$ & $\begin{array}{l}\text { Gravels with clasts of quarzite (56\%) and quartz } \\
(44 \%) . \mathrm{MPS}=22 \mathrm{~cm}\end{array}$ & Not found \\
\hline T4 terrace & $\begin{array}{l}38 \mathrm{~m} \text { a.s.l. }+30 \mathrm{~m} \\
\text { (a.r.b.) }\end{array}$ & $52 \mathrm{~m}$ & $25-30 \mathrm{~m}$ & $\begin{array}{l}\text { Gravels with clasts of quarzite (68\%) and quartz } \\
(32 \%) . \text { MPS }=20 \mathrm{~cm} \text {. Sands and clays. }\end{array}$ & $\begin{array}{l}\text { Achaeulean; Vale do Forno; Vale da } \\
\text { Atela; Quinta da Boavista; Ribeira da } \\
\text { Ponte da Pedra }\end{array}$ \\
\hline $\begin{array}{l}\text { T5 terrace (partially } \\
\text { buried) }\end{array}$ & $\begin{array}{l}15 \mathrm{~m} \text { a.s.l. }+7 \mathrm{~m} \\
\text { (a.r.b.) }\end{array}$ & $33 \mathrm{~m}$ & ca. $9-10 \mathrm{~m} \mathrm{~m}$ & Coarse to fine sands and clays & Mousterian; S. Antão do Tojal \\
\hline T6 terrace (buried) & $\begin{array}{l}-4 \mathrm{~m} \text { a.s.l. }-12 \mathrm{~m} \\
\text { (a.r.b.) }\end{array}$ & ca. $37 \mathrm{~m}$ & ca. $18 \mathrm{~m}$ & Very coarse gravelly sands & Late Mousterian; Santa Cita \\
\hline Alluvial plain & $\begin{array}{l}10 \mathrm{~m} \text { a.s.l. }+2 \mathrm{~m} \\
\text { (a.r.b.) }\end{array}$ & ca. $24 \mathrm{~m}$ & ca. $30 \mathrm{~m}$ & Silty clays and coarse to fine sands & $\begin{array}{l}\text { Mesolithic and more recent industries } \\
\text { (several sites) }\end{array}$ \\
\hline
\end{tabular}

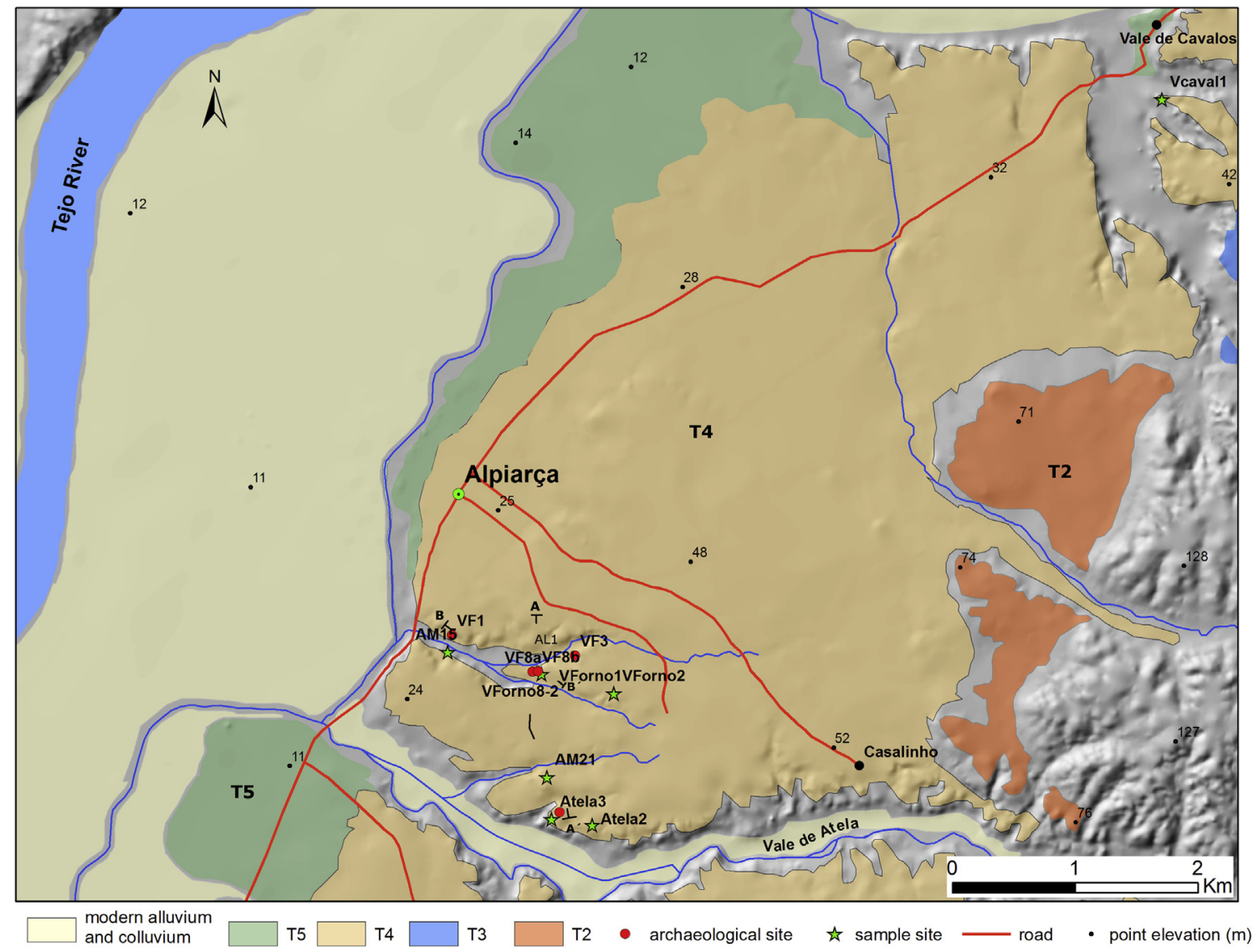

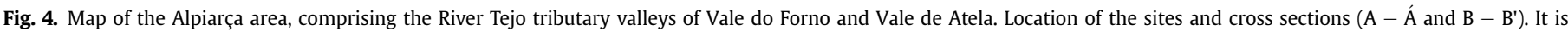
deduced from the contour lines that the interfluves between the Vale do Forno and Vale de Atela is developed in eroded (dissected) uppermost T4 deposits.

in lithofacies Fm, positioned in the middle part of the US unit between 27 and $21 \mathrm{~m}$ a.s.l.. Each palaeosol can be traced over a wide area of some $4 \mathrm{~km}^{2}$, being observed in numerous sections. The main palaeosol characteristics are reported in Table 2. All palaeosols show abundant mottles and coatings of Fe-Mn oxides along cracks and on the faces of soil aggregates, as well as slickensides and pressure faces in the more clayey horizons. These features are indicative of poorly drained soils within a fine-grained floodplain (Aslan and Autin, 1998). Slickensides and pressure faces suggest the occurrence of significant variations in soil water content (Dinka et al., 2013), implying strong seasonal variability with summer drought. Palaeosols displaying seasonal wet-dry cycles cover an 


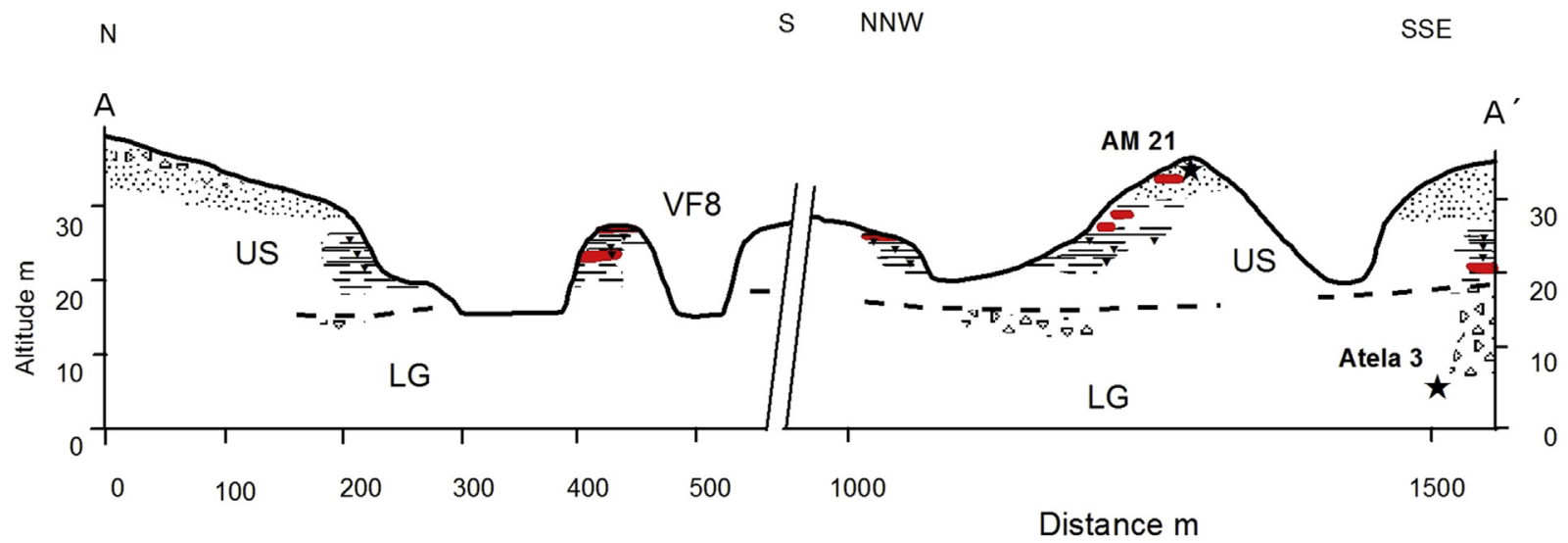

Legend

* OSL samples - - - Disconformity LG/US

- Palaeolithic archaeological site

Sandy channel deposits Overbank fines

Fig. 5. Stratigraphic cross section A - A'. See Fig. 4 for location of the cross section and location of the OSL samples AM 21 and Atela 3.

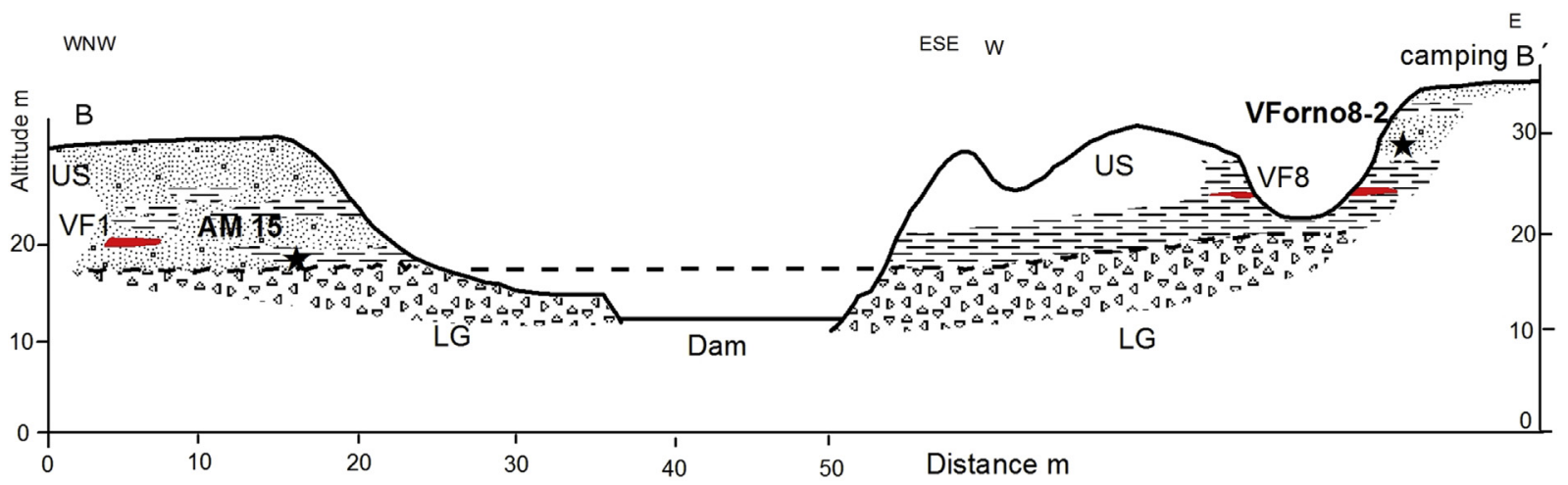

Legend

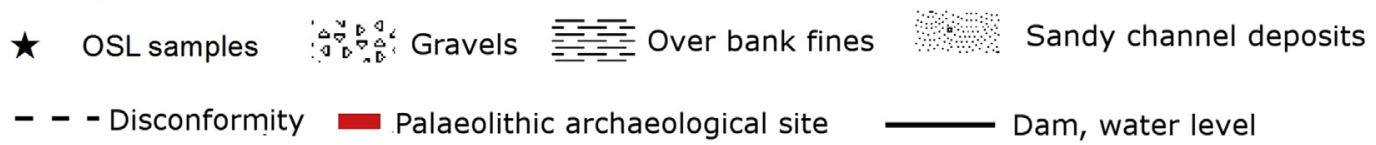

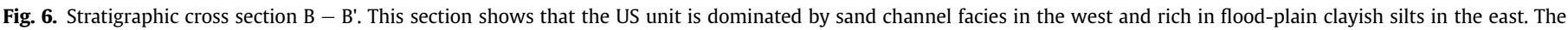
topographic position of sample AM 15 is at near distance from the cross section (see Fig. 4), in the west side of the Vale do Forno streamlet.

area of several square kilometers, which suggests that they are not localized occurrences associated with periodic channel levee breaching. Instead, each palaeosol seems to be indicative of wider floodplain stability and, thus, corresponds to a potential hiatus in the sedimentary sequence. The degree of evolution of the palaeosol profile may provide some clue as to the time scale involved in its formation (Huggett, 1998; Zielhofer et al., 2009). For example, the observed palaeosol characteristics can commonly form in relatively short time spans, possibly in the order of $10^{3}-10^{4}$ years (Yaalon, 1983). Nevertheless, it must be pointed out that the hydromorphic setting in which soil formation occurred is not adequate for producing unequivocal soil chronosequences, as the soil hydrology is expected to be a major controlling factor which may severely limit the evolution of the soil profile. As time may not be a predominant factor, the above time intervals should be regarded only as minimal age constraints.

\subsection{Lithic industries}

The supposedly "Early Acheulian" industries were found in the LG unit by Zbyszewski (1946). Part of this unit is presently submerged by a local dam and for the last two decades it has not been possible to find additional artefacts in situ.

In contrast, archaeological sites are numerous in several stratigraphic levels within the US unit. Acheulian industries, containing "large cutting tools", such as bifaces, cleavers and sidescrapers are present. Clear Middle Palaeolithic industries, the so-called "flake industries" or Mousterian, based on specific core reduction sequences (mainly discoid or Levallois), with no relevant occurrence of large cutting tools, are almost absent. In contrast, bifaces and cleavers do occur throughout the alluvial sequence, evolving technologically and typologically. Here, we summarize the three main archaeological sites excavated from the US unit in the Vale do 

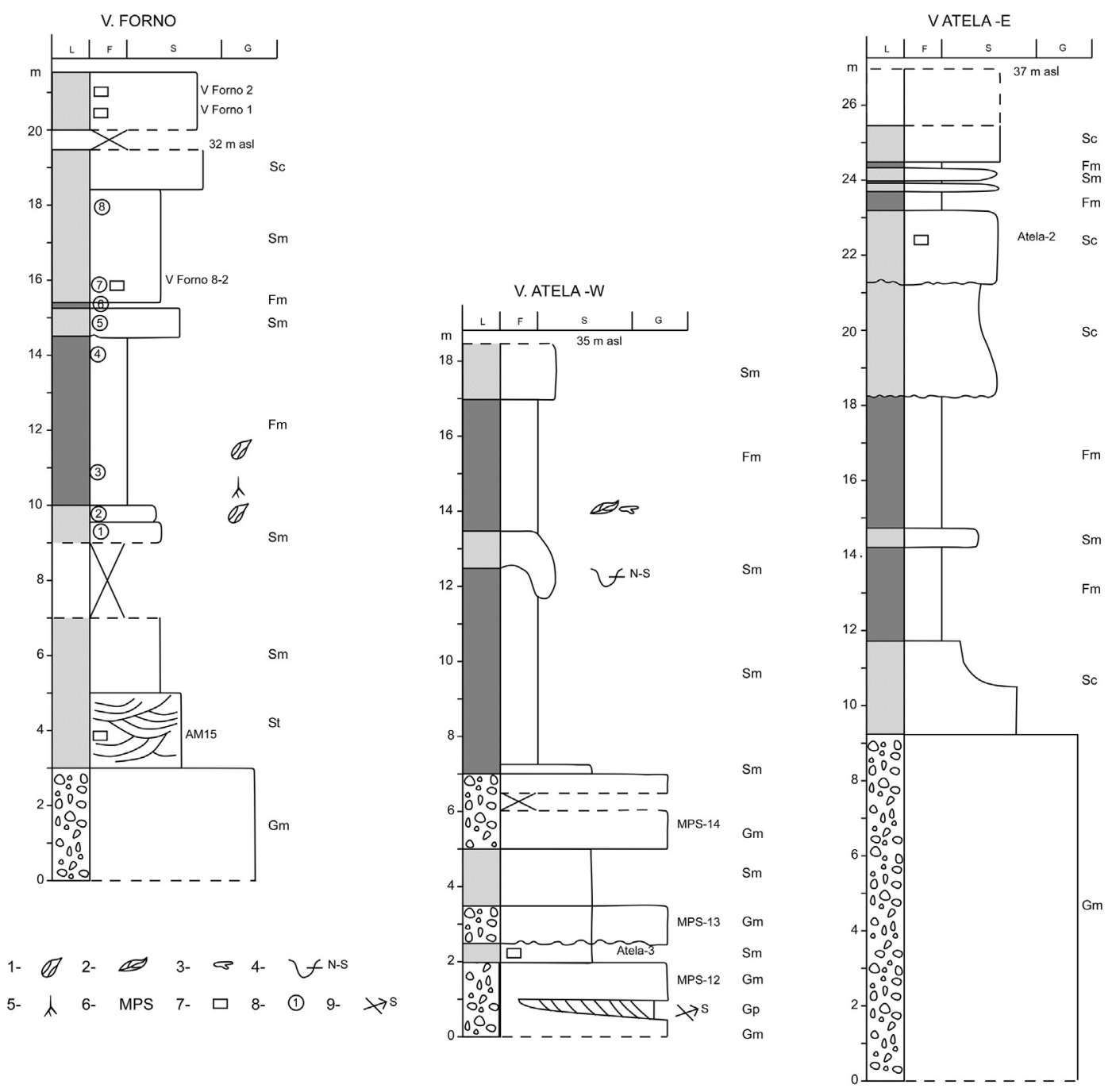

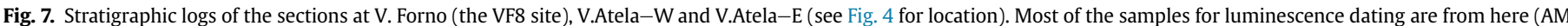

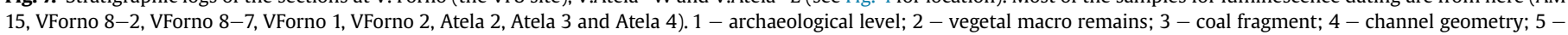

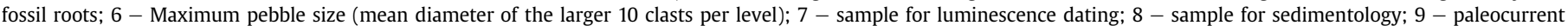
derived from planar cross-bedding.

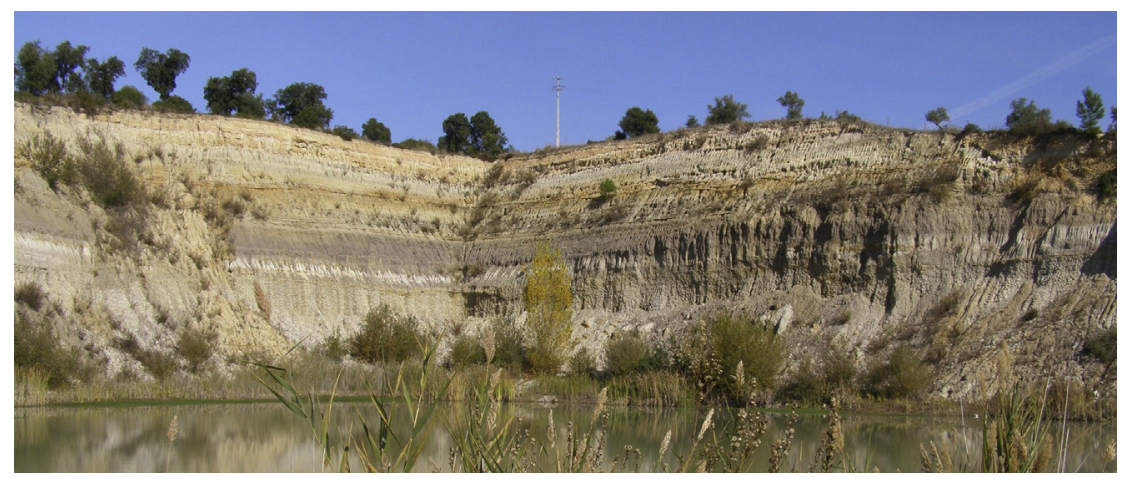

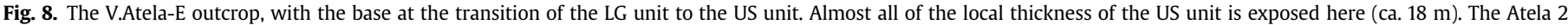
sample was collected at $\sim 2.5 \mathrm{~m}$ below the cliff top.

Forno area, described in stratigraphic sequence (VF1, VF8 and VF3). The large number of artefacts discovered allows for a cultural diagnosis of the industries.
The VF1 site (Vale do Forno; Figs. 4 and 6) was found lowermost in the stratigraphy, within the basal channel sandy deposits of the US unit. Typologically, the lithic industry is represented by poorly 


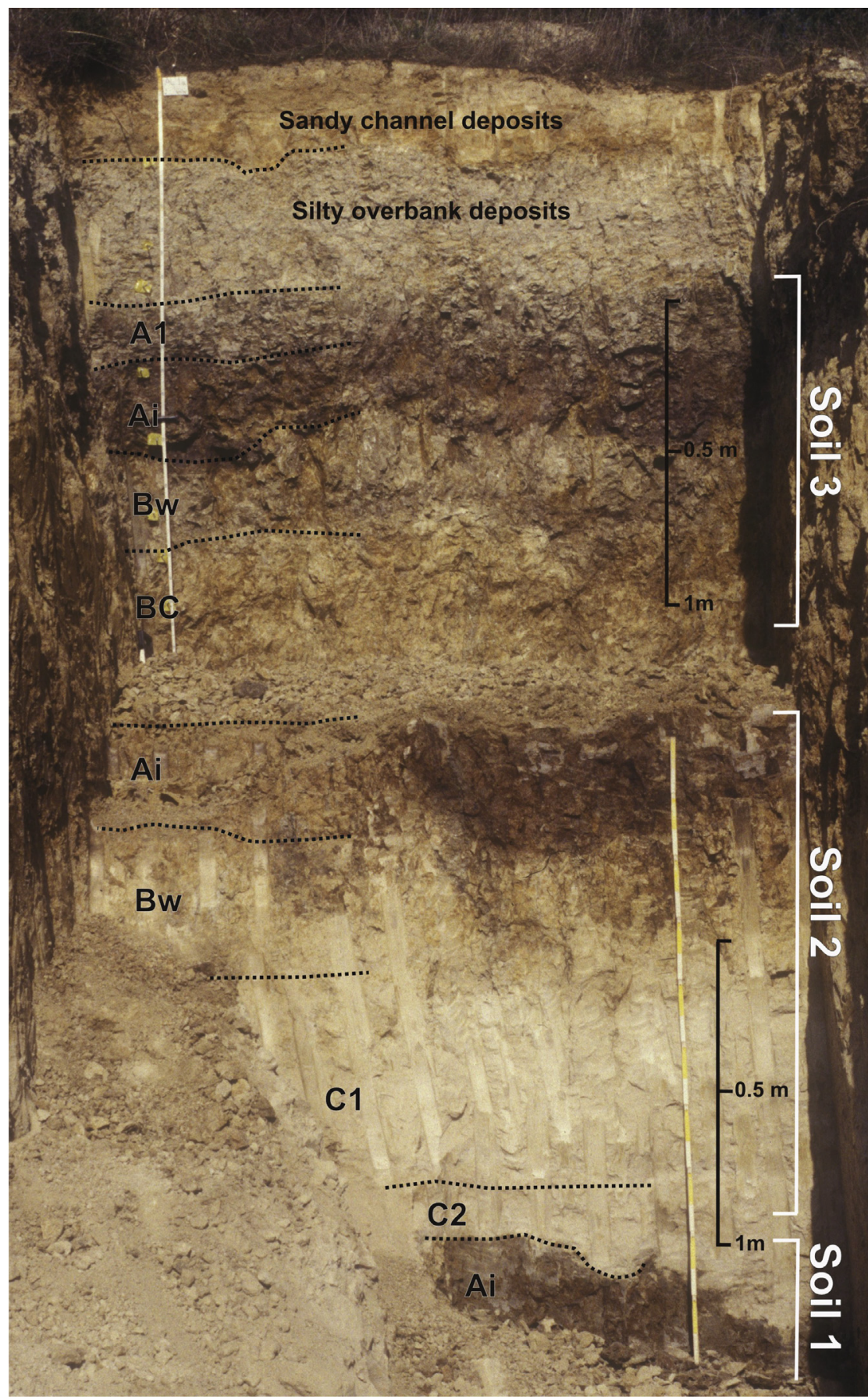

Fig. 9. Paleosols developed in the overbank deposits of the T4 terrace US unit, at the AL1 site (see Fig. 4 for location).

evolved Acheulian tool types (Fig. 10). It contains a high percentage of flaked pebbles, unifacial choppers and hand axes, all of a quite rough manufacture; flakes show few implements.

At the VF8 site (Vale do Forno; Figs. 4-7 and 11 and 12) artefacts were recovered from the upper part of the US unit from a fine sand level (facies Sm) and an immediately overlying clayish silty bed (Fm). Approximately three thousand artefacts have been recovered from a thin archaeological horizon (ca. $10 \mathrm{~cm}$-thick) interbedded in clays. A high concentration of flaked lithic materials ( $\sim 140$ artefacts per $\mathrm{m}^{2}$ from an excavated area of $20 \mathrm{~m}^{2}$ ) and the presence of the entire reduction sequences, from manuports and tested cobles, cores, initial flakes and large tools up to small retouched tools and abandoned debris, documents both the integrity of the site and the fact that local flaking activities were taking place in a flood-plain environment. Final retouched tools represent 15\% of the total industry including waste products (or 24\% without them). This observation is even more significant giving that finished tools represent more than $30 \%$ of the total weight of the lithic products, something that is directly related to the presence of the characteristic Acheulian large cutting tools. These large Acheulian tools are minor in numeric terms: $5 \%$ of bifaces and cleavers ("hachereaux") and $9 \%$ of choppers and chopping-tools. Most of the retouched artefacts are retouched tools on flake (84\% in numeric terms; $42 \%$ concerning weight), dominated by notches and 
Table 2

The main features of palaeosols within the US unit.

\begin{tabular}{|c|c|c|c|c|c|c|c|}
\hline Horizo & $\begin{array}{l}\text { Thickness } \\
(\mathrm{cm})\end{array}$ & Grain size & $\begin{array}{l}\text { Colour } \\
\text { (Munsell) }\end{array}$ & Structure & $\begin{array}{l}\text { Slickensides pressure } \\
\text { faces }\end{array}$ & Lower boundary & Other features \\
\hline \multicolumn{8}{|c|}{ Soil 3 (upper) } \\
\hline $\mathrm{A} 1$ & 35 & silty clay & 10 YR $5 / 2$ & $\begin{array}{l}\text { very coarse platy from sedimentary } \\
\text { laminae }\end{array}$ & common & clear smooth & - \\
\hline $\mathrm{Ai}$ & 40 & silty clay & $10 \mathrm{YR}$ & strong coarse prismatic & abundant & abrupt irregular & - \\
\hline Bw & 50 & Silt & $5 Y 6 / 3$ & strong coarse prismatic & - & clear wavy & - \\
\hline $\mathrm{BCi}$ & 95 & clayey silt & $2.5 Y 6 / 2$ & moderate coarse prismatic & common & gradual & transition to $\mathrm{Ai}$ hor. of soil 2 \\
\hline \multicolumn{8}{|c|}{ Soil 2 (middle) } \\
\hline $\mathrm{Ai}$ & 35 & silty clay & 10 YR $5 / 3$ & strong coarse prismatic & abundant & $\begin{array}{l}\text { clear wavy to } \\
\text { irregular }\end{array}$ & - \\
\hline Bw & 60 & Silt & $2.5 Y 5 / 4$ & $\begin{array}{l}\text { strong coarse prismatic to angular } \\
\text { blocky }\end{array}$ & - & gradual smooth & - \\
\hline $\mathrm{C} 1$ & 70 & sandy silt & $2.5 Y 6 / 4$ & massive & - & Gradual smooth & - \\
\hline $\mathrm{C} 2$ & $20-40$ & $\begin{array}{l}\text { silty coarse } \\
\text { sand }\end{array}$ & $2.5 Y 6 / 4$ & massive & - & abrupt wavy & locally erosive on Ai hor. of soil 1 \\
\hline \multicolumn{8}{|c|}{ Soil 1 (lower) } \\
\hline $\mathrm{Ai}$ & 40 & silty clay & 10 YR $5 / 3$ & strong coarse prismatic & Abundant & clear smooth & - \\
\hline Bw & 25 & Silt & $2.5 Y 6 / 4$ & moderate coarse angular blocky & - & abrupt wavy & abundant bioturbation \\
\hline $\mathrm{Cm}$ & 55 & Silt & $2.5 Y 6 / 4$ & $\begin{array}{l}\text { weak coarse angular blocky to } \\
\text { massive }\end{array}$ & - & unknown & $\begin{array}{l}1 \mathrm{~cm} \text {-thick iron crust, abundant Fe-Mn } \\
\text { nodules }\end{array}$ \\
\hline
\end{tabular}

denticulates, sidescrapers, dorsal knives, borers and "becs" (a Palaeolithic flake boring tool retouched on one edge to form a point). Discoid centripetal reduction sequences are rare and the Levallois method is absent.

The VF3 site (Milharós, Fig. 4) provided an assemblage of artefacts found on a thin layer located between a fluvial sandy silt level at the T4 terrace top and a colluvial deposit associated with aeolian sands (Raposo, 1996). After the archaeological excavation, a camping site (Fig. 6) was constructed on the VF3 site and later sampling for luminescence dating was not possible. However, the VF3 industry postdates the T4 terrace and predates the deposition of the Carregueira Formation (the aeolian unit covering the terrace). This stratigraphic position is important for understanding the likelihood of a much younger age for this typologically much evolved Acheulian industry, the so-called Micoquian. The VF3 lithic industry is mainly of quartzite composition with the most important typological groups being: bifaces (8\%) cleavers (4\%), sidescrapers $(9 \%)$, pebble tools (15\%), flake tools $(9 \%)$, cores $(13 \%)$ and flakes (42\%) (Figs. 13 and 14).

This degree of evolution, and the highly standardized character of the bifaces that are made from quartzite, indicate that the raw material did not constitute an impediment to producing evolved tools. The level of sophistication is similar to that of bifaces manufactured from flint, a raw material that is much more favourable for long knapping and retouching sequences than quartzite. Typologically (according to the Jacques Tixier system), cleavers from the VF3 appear to be quite "primitive". However, this primitiveness is probably more apparent than real, and is probably related to the nature of the typological system in use - this is mainly technologically oriented, rather than morphologically oriented as it is more common in all traditional typological systems. In fact, due to the absence of the Levallois method and its corresponding flaked products, all cleavers are made on large entirely cortical or semi-cortical flakes, obtained from large cobles. These flakes have been referred to as "Acheulian flakes" since the 1940s (Zbyszewski, 1943). These flakes comprise a much more standardized support, either in terms of thickness indexes as in term of elongation indexes. The flaking platform is almost always cortical (rarely planar) and is often laterally situated, tending sometimes to the lower, proximal sector of the flake. From a strictly morphological point of view, the cleavers made on these flakes are as evolved as the bifaces (Raposo, 1996). They show high degrees of symmetry, corresponding to what can be considered the geometrical "mental template" of the prehistoric artisan. So, the differences between "evolved" bifaces and apparently "primitive" cleavers seems to derive from the intention of the Acheulian artisan to use a more complex reduction sequence to obtain the bifaces (successive retouch and edge refining) and to adopt a very limited knapping sequence to produce cleavers. The difference between the refinement procedures of the bifaces and cleavers seems to be more related to the system of classification used: a system oriented to the morphological evaluation, in the case of the bifaces, and a system of classification oriented to the evaluation of the technological procedures, in case of cleavers.

Recently published evidence from Britain recognizes assemblages with these same two distinctive handaxe types (cleavers and 'lanceolate' forms) in combined assemblages dating from around Marine Isotope Stage (MIS) 9, with the chronology based on the position of such assemblages within the well-dated sequence of the Thames and its tributaries (Bridgland and White, 2014, 2015). This new evidence arises from a reappraisal of high-integrity assemblages of handaxes recognized by Roe (1968) (also see Chauhan et al., this volume).

However, the VF3 bifaces are also similar to those found in the Manzanares Valley Complex Terrace of Butarque (near Madrid, $\sim 400 \mathrm{~km}$ away), which Middle Palaeolithic stone tools have been dated to between the final Middle Pleistocene (MIS 6, 190-130 ka) and the early Late Pleistocene (MIS 5, 130-71 ka) (Panera et al. 2014), but also in several other areas of the Iberian Peninsula, where more evolved tools, such as lanceolate bifaces and Micoquian forms, surpass the more "primitive" ovate and amygdaloid forms.

Based on the above discussion, we consider that the VF3 industry is likely to represent an occupation on the surface of the US shortly after its deposition.

\subsection{Luminescence dating}

Quartz-OSL could only be applied to one palaeosample (132201) and to the two modern river bed samples $(102232,102263)$; for all the other samples the quartz natural OSL signals are too close to saturation to be useful for dating. For these older samples, signals from K-rich feldspars were used instead because of the higher saturation dose of the feldspar dose response curve (inset Fig. 15a; 

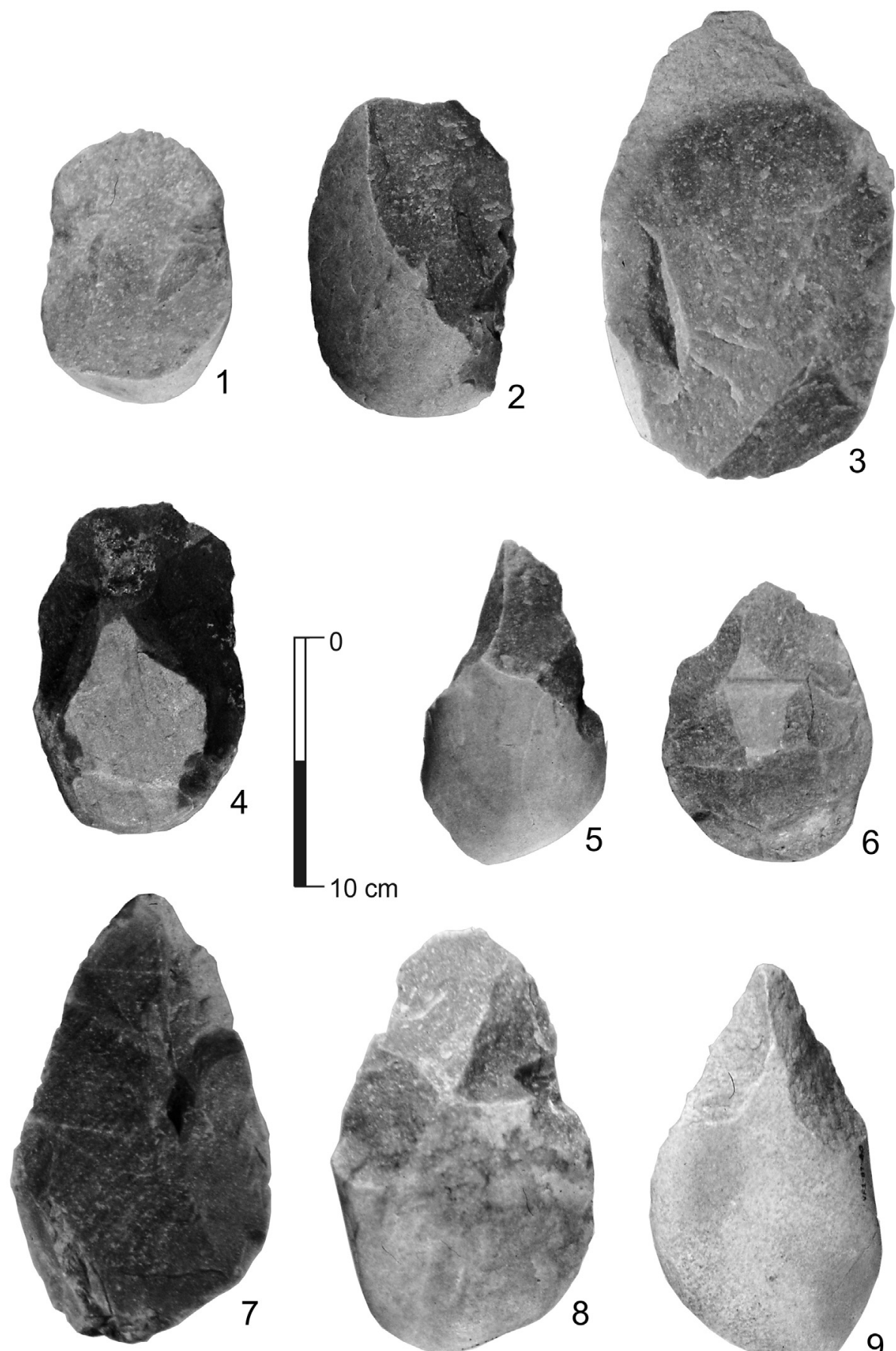

$10 \mathrm{~cm}$
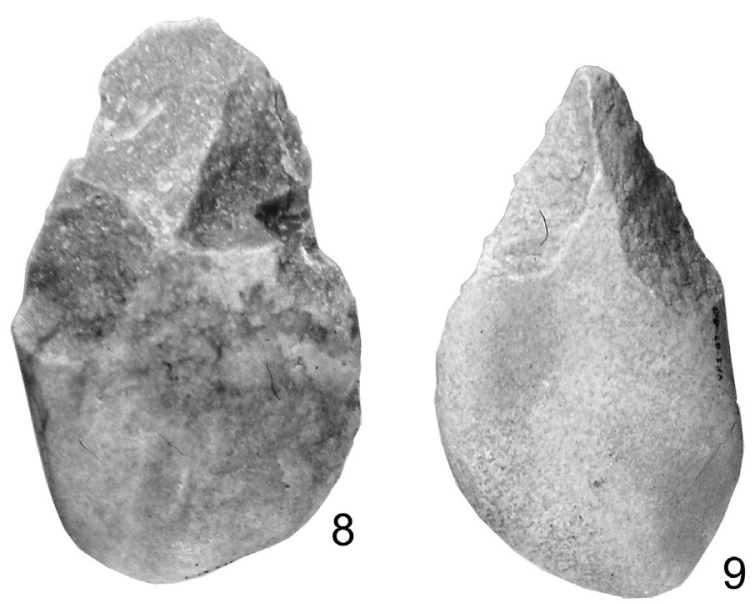

Fig. 10. Large Acheulian cutting tools from VF1 site. 1 to 4 - Cleavers; 5 to 9 - Bifaces.

$\mathrm{D}_{0}$ of $\sim 500 \mathrm{~Gy}$, compared to typically $\sim 80 \mathrm{~Gy}$ for fast OSL component in quartz; Wintle and Murray, 2006). The pIRIR 290 signal from feldspar was chosen because of its stability (Buylaert et al., 2012). We have also undertaken several direct tests of the stability of the pIRIR $_{290}$ signal, the suitability of the applied measurement protocol and the completeness of bleaching of this signal at deposition.

Buylaert et al. (2012) have suggested the use of first IR stimulation plateaus to examine the stability of the pIRIR 290 signal. We have measured such a plateau for sample 102226 collected in the T1 terrace, estimated to have an age of ca. 1.1-0.9 Ma by ESR and OSL dating of the terrace staircase (Cunha et al., 2012, 2016; Rosina et al., 2014; Martins et al., 2010a, 2010b). This sample is old enough that its natural pIRIR 290 signal is expected to lie at or close to the saturation in the dose response curve (samples of so-called nonfinite luminescence age). The ratio of natural pIRIR 290 signal to the saturation level of the dose response curve varies between 0.93 and 0.95 for first IR stimulations varying between $50^{\circ} \mathrm{C}$ and $230^{\circ} \mathrm{C}$. This demonstrates that the pIRIR $_{290}$ signal is sufficiently stable for dating (effects of fading in nature $<10 \%$ ) and we have adopted $50{ }^{\circ} \mathrm{C}$ as a suitable prior IR stimulation temperature.

The reliability of the SAR pIRIR 290 dose measurement protocol was further tested using a dose recovery test based on two modern 

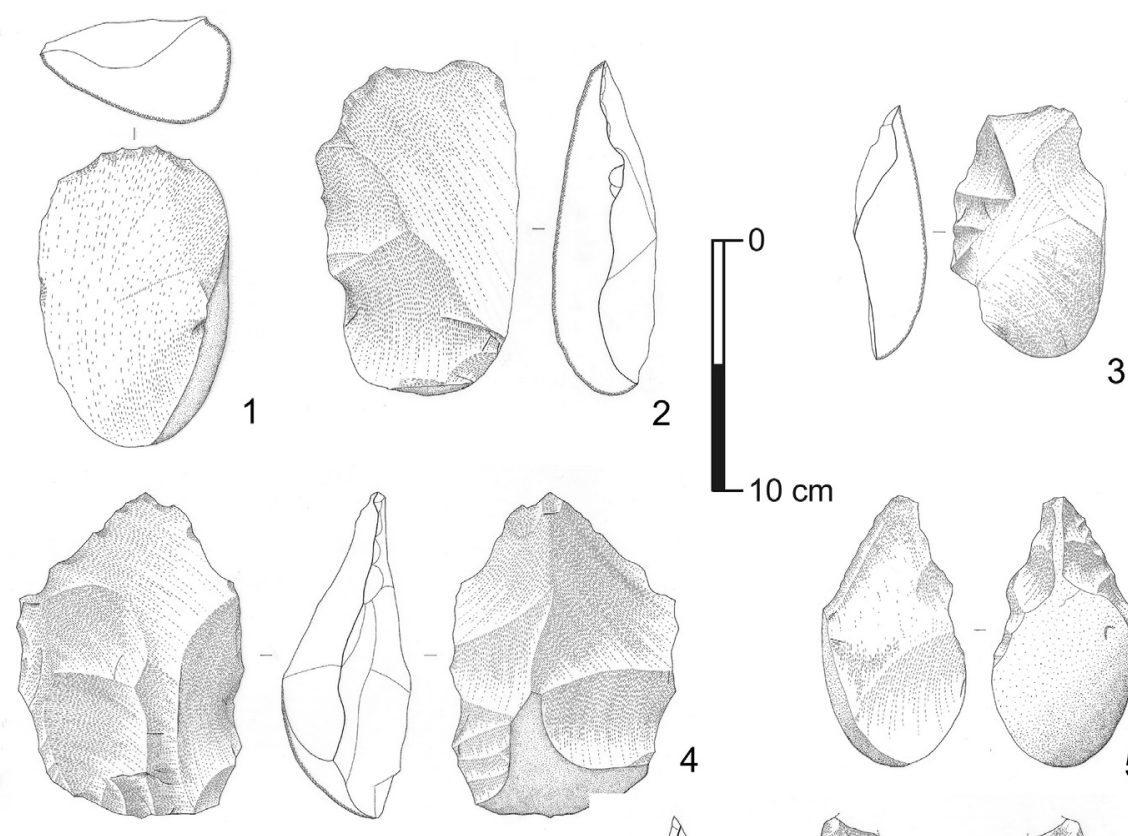

$-10 \mathrm{~cm}$

\section{4}
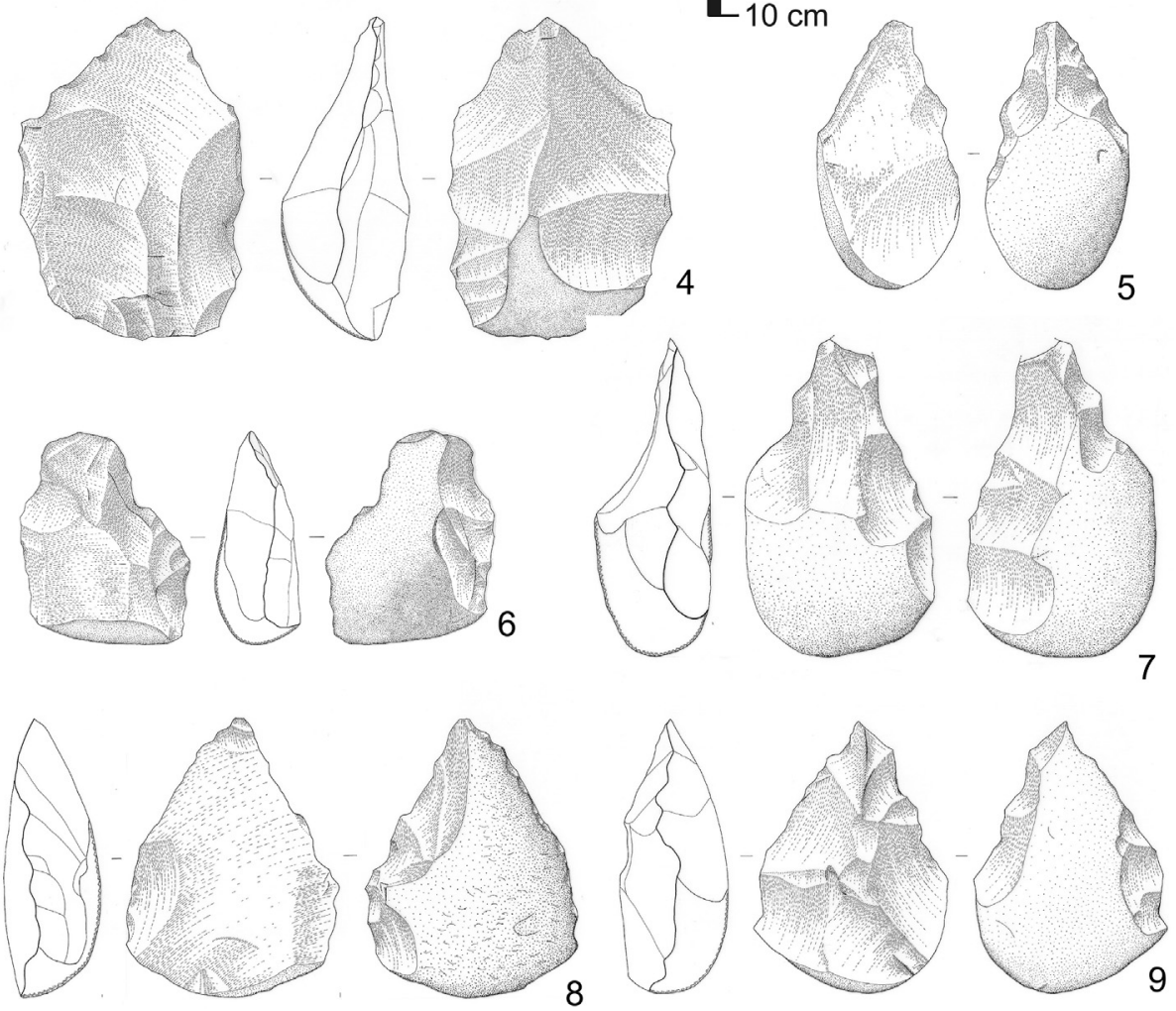

Fig. 11. The Acheulian industry of VF8 site. Large cutting tools. 1 to 4 - Cleavers; 5 to 9 - Bifaces.

river bed samples (102232 and 102263). Laboratory beta doses ranging from $\sim 15$ to $\sim 800 \mathrm{~Gy}$ were added to natural aliquots of these two samples and measured in the usual manner. The measured doses (after subtraction of the small natural dose) are plotted as a function of the given laboratory doses in Fig. 15b. It can be seen that large laboratory doses, given prior to heat treatment, can be accurately recovered with this protocol.

It is obviously important to be confident that the pIRIR 290 signal was well-bleached at deposition. For the single aeolian sample (132201) the agreement with the quartz age control confirms adequate bleaching prior to deposition. For the fluvial samples we have two lines of argument. First of all we have taken two sand samples currently in transport from the modern channel (102232 and 102263) and these both give pIRIR $290 D_{e}$ values $\leq 20 \mathrm{~Gy}$, small or negligible compared with the other fluvial doses in this study (between 180 Gy and saturation). Secondly, Murray et al. (2012) and Buylaert et al. $(2012,2013)$ have shown by exposing natural samples to artificial sunlight for different lengths of time that the pIRIR $_{290}$ signal bleaches much more slowly than the $I_{50}$ signal. This differential bleaching rate can be used to identify samples for which the pIRIR 290 signal is likely to be well-bleached (Murray et al., 2012; Buylaert et al., 2013). Fig. 15c shows the $I_{50} D_{e}$ values as a function of the pIRIR $290 D_{e}$ values. The data are consistent with a smooth curve passing through the origin. The absence of obvious outliers suggests that all pIRIR 290 signals were probably well-bleached at deposition in comparison with their subsequent burial doses. It could be argued that the two samples lying below the line on the pIRIR 290 axis might suggest incomplete bleaching of the pIRIR 290 signal. But we are fortunate that the sample (102233; $81 \pm 4 \mathrm{ka}$ ) lying immediately above the layer with independent U-series age control (81.9 + 4.0/-3.8 ka; Raposo, 1995a) lies in this group, clearly confirming that this sample was adequately bleached. The sample immediately below (102263; $75 \pm 14 \mathrm{ka}$ ) is also consistent with the age control and with a pIRIR $_{290} D_{e}$ of $200 \pm 35$ Gy lies on the smooth line (Fig. 15c).

Six out of the nineteen samples reported in Tables 3 and 4 have $\mathrm{D}_{\mathrm{e}}$ values lying above $2 \mathrm{xD}_{0}$ (corresponding to $86 \%$ of luminescence saturation). Especially in view of the possibility of small systematic errors in the measurement of the luminescence signal (Fig. 15a), we feel it prudent to adopt the strategy suggested by Wintle and 

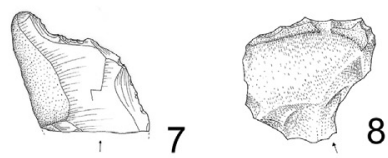

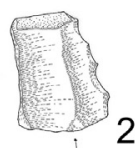

2

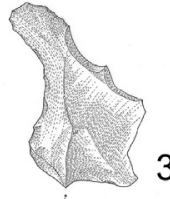

3

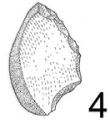

4

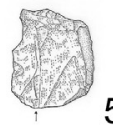

5

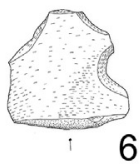

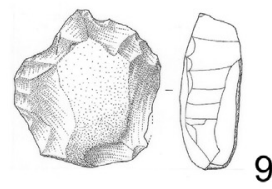

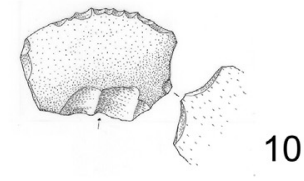

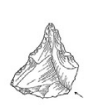

11
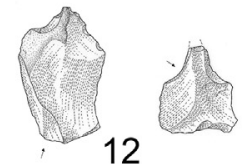

13
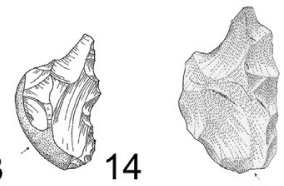

15

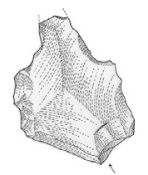

16

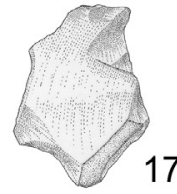

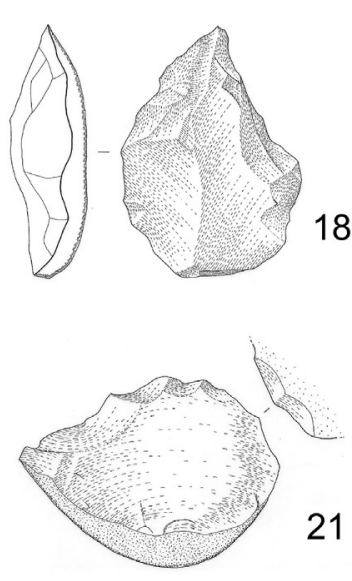
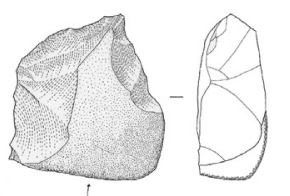

19
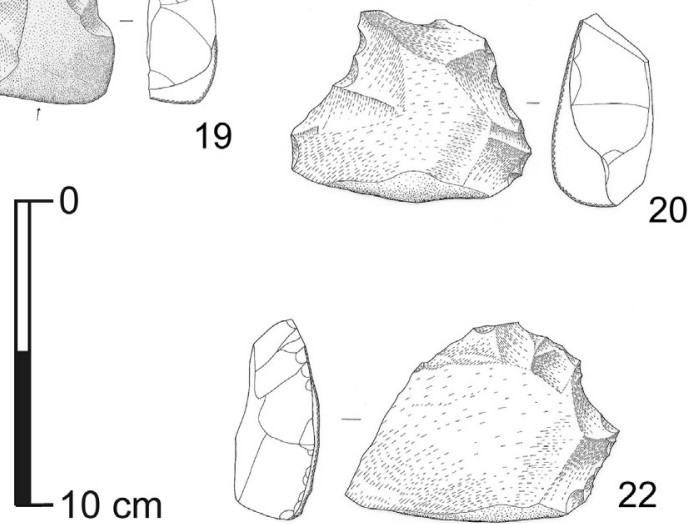

Fig. 12. The Acheulian industry of VF8 site. Flake tools. 1 to 6 - Denticulates and notches; 7 to 10 - Sidescrapers; 11 to 20 - Borers; 21 and 22 - Scrapers on ventral face.

Murray (2006) of only presenting minimum doses for these samples (equivalent to $2 \mathrm{xD}_{0}$ ) and the derived minimum ages. We also note that our measurement protocol has only been tested against independent age control up to $\sim 2 \mathrm{xD}_{0}$ (Buylaert et al., 2012).

To constrain the artefacts stratigraphically, most of the samples were collected in T4, at the Vale do Forno and Vale de Atela sections (Fig. 4). Others samples were collected in outcrops of T5 (Figs. 3 and 16), one sample in the aeolian sands of the Carregueira Formation and two samples from the river bed (modern). The luminescence dating results are all summarised in Tables 3 and 4

As stated above, dating by the pIRIR 290 protocol was tested using two samples from the topmost deposits of the T5 terrace of a Tejo tributary, at Santo Antão do Tojal (near Vila Franca de Xira; Fig. 2) from which a large elephant bone was collected and dated by using the U/Th series (Raposo, 1995a). The pIRIR 290 ages of the samples Atojal-1 and Atojal-2 (Table 4), taken from the same stratigraphic levels, corroborate the independent age obtained by the U/Th series $(81.9+4.0 /-3.8 \mathrm{ka})$.

Sample 132203 (Atela 3) was collected in the LG unit, from a gravel pit situated in the right-bank (northern side) of the Vale de
Atela (V.Atela-W) (Figs. 4, 5 and 7). Stratigraphically, it is the lowest sample of the terrace T4 (LG - middle part), collected in the Alpiarça area. Because the natural pIRIR 290 signal is in saturation only a minimum age of $>200 \mathrm{ka}$ is given (Table 4 ).

The samples collected at the base of the US unit (AM-22 and VCaval-1) all gave minimum ages, respectively of $>270 \mathrm{ka}$ and $>200$ ka. Sample 052216 (AM-15) (>270 ka) was taken below the levels containing the Late Acheulian artefacts of the VF8 site and the other samples from sites located far away (Figs. 3, 4 and 17), but in an equivalent stratigraphic level of the sample AM 15.

From the middle part of the US unit a minimum age (AM-21; $>300 \mathrm{ka}$ ) and a finite age (VForno 8-2; $201 \pm 16 \mathrm{ka}$ ), were obtained. The VForno 8-2 sample is located $4 \mathrm{~m}$ above the stratigraphic level containing the VF8 artefacts (Figs. 4, 6 and 7) and therefore the artefacts of the VF8 site are older than $200 \mathrm{ka}$ and, probably somewhat older than $300 \mathrm{ka}$.

Sample Atela 2 (132202) was collected at ca. $2.5 \mathrm{~m}$ below the local eroded surface of the T4 terrace and provided a minimum age (>200 ka). The samples VForno-1 (132244) and VForno-2 (132245) were collected at the T4 topmost deposits (Figs. 4 and 7) and gave 

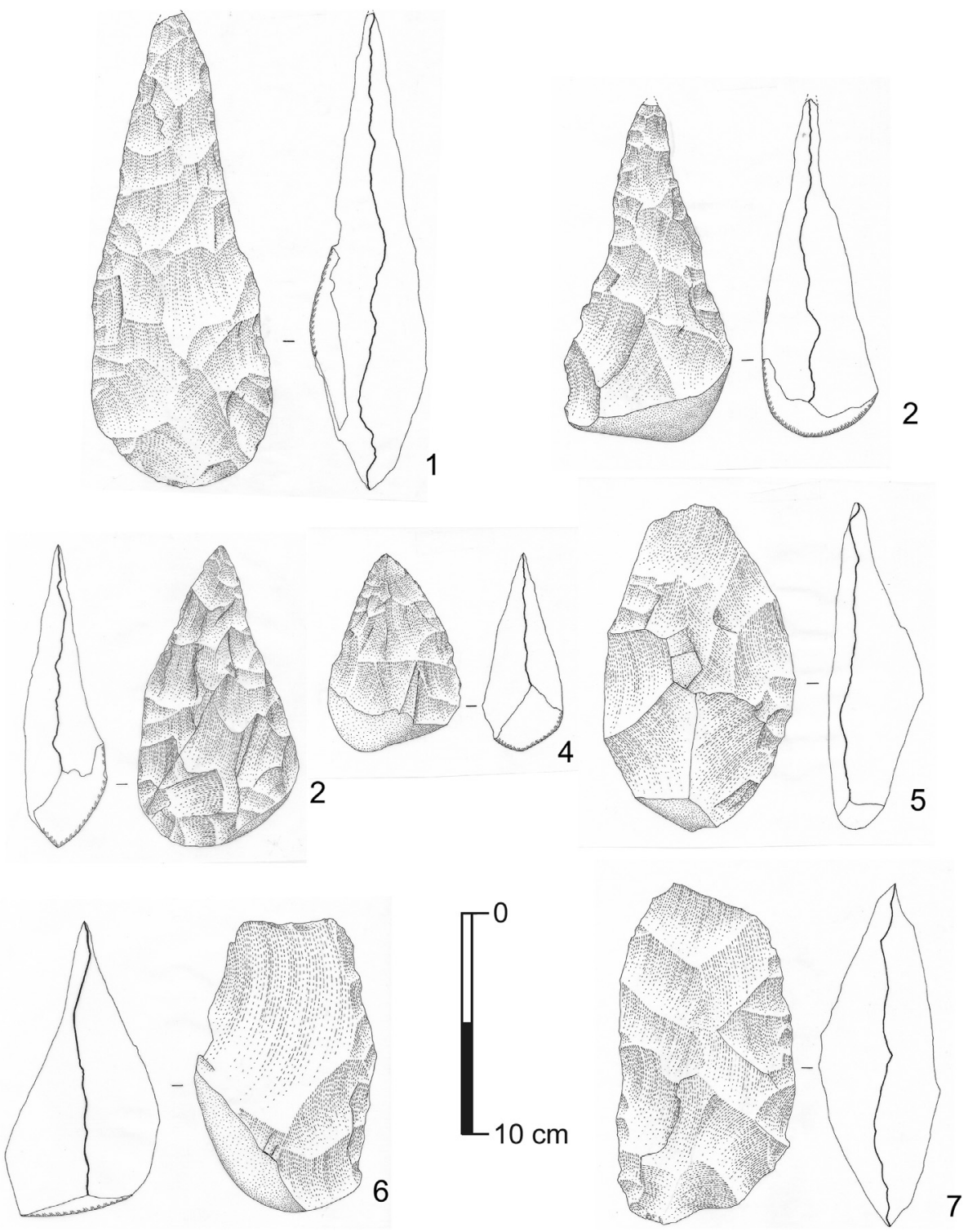

Fig. 13. The final Achdeulian industry of VF3 site (Milharós site). Bifacial tools. 1 to 5 - Bifaces (Micoquian, lanceolate, ovalar); 6 and 7 - Bifaces with distal cutting edge.

ages of $158 \pm 9$ and $154 \pm 10 \mathrm{ka}$, that are stratigraphically correct.

Throughout the T4 sequence, the finite luminescence ages are always stratigraphically correct. Due to the high dose rates, the LG unit and the base of the US unit were found outside the upper range of the pIRIR 290 method. Sediments of the middle and upper part of the US unit provided finite ages (not minimum) only occasionally. The topmost deposits of the T4 terrace are on the threshold of the dating method and have an age of ca. $155 \mathrm{ka}$.

In summary, the new pIRIR 290 ages for the T4 deposits in the study area indicate that:

1) The LG unit, containing the artefacts reported by Zbyszewski (1946), has an age much older than $300 \mathrm{ka}$;

2) The lower and middle part of the US unit, containing the VF1 and VF8 Acheulian industries, has a probable age of ca. 325 to $200 \mathrm{ka}$;

3) The upper part of the US unit has an age of 200 to $155 \mathrm{ka}$

Samples Muge-1 (PC5239), Muge-2 (PC5240) and PSabug-2 (102231), collected from the T5 top deposits (Fig. 16), yielded ages of ca. 95 to $75 \mathrm{ka}$.

The sample Azinh-3 (39 $\pm 2 \mathrm{ka}$ ), taken from the topmost deposits of the terrace mapped near the village of Azinhaga (Fig. 3), confirms the geomorphological correlation of this terrace with the T6 level. From other luminescence dating studies, the T6 terrace has been dated as ca. $65 \mathrm{ka}$ (base deposits) to ca. $32 \mathrm{ka}$ (top deposits) and correlated with MIS 3 (Martins et al., 2010a, 2010b; Cunha et al., 2008, 2012).

Finally, the aeolian sands of the Carregueira Formation, that covers the T5 and T4 terraces in the study area, was dated at Almeirim (sample Almer-1; 132201) as $19.1 \pm 1.1 \mathrm{ka}$ (Quartz-OSL).

\section{Discussion}

In an environment of continuous uplift, the formation of fluvial terraces has been correlated with climate changes (e.g. Gibbard and Lewin, 2002; Bridgland and Westaway, 2008; Bull, 2009) but lower reaches could be dominated by sea-level changes (e.g. Merritts et al., 1994; Blum and Törnqvist, 2000; Lewis et al., 2004). The data obtained in the study area indicate that the terrace 

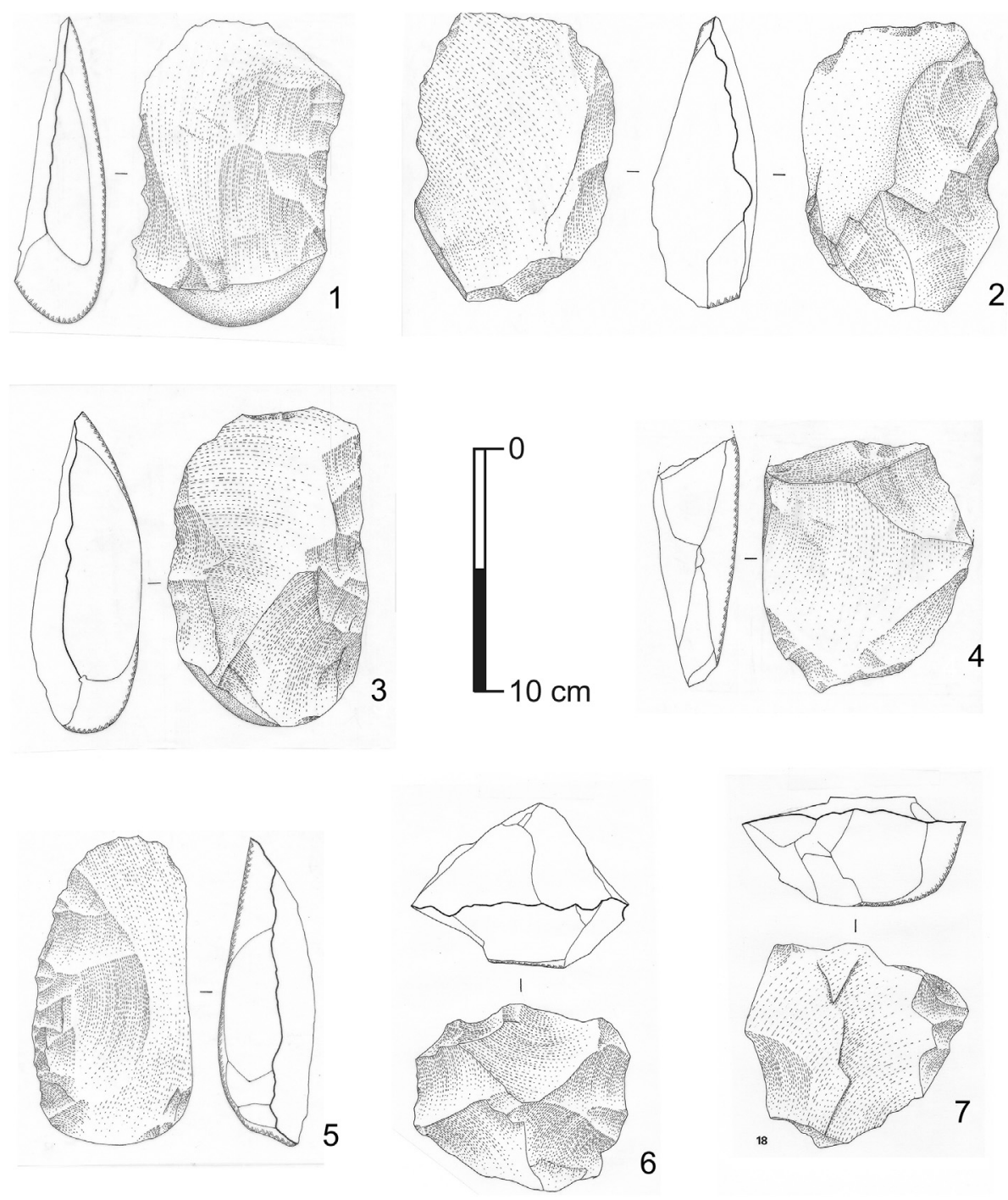

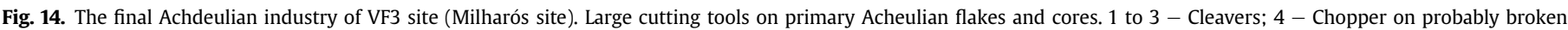
cleaver; 5 - Sidescraper; 6 - Bypiramidal core; 7 - Proto-Levallois core.

aggradation episodes can be correlated with the Marine Isotope Stages (MIS; e.g. Wright, 2000; Lisiecki and Raymo, 2005). Being much older than $300 \mathrm{ka}$, the LG unit most likely corresponds to the earlier part of the MIS 9 (337-325 ka), immediately postdating incision promoted by the very low sea level (reaching ca. $-140 \mathrm{~m}$ ) during MIS 10 (362-337 ka) (Fig. 17). This suggests that the aggradation of the coarse-grained $\mathrm{T} 4$ terrace base has probably occurred during a period of low sea level and relatively cold climatic conditions (e.g. Gibbard and Lewin, 2002), probably marked by sparse vegetation cover on slopes (Roucoux et al., 2006). This climate relationship for valley floor aggradation is typical of many large European river systems (e.g. Bridgland and Westaway, 2008). During the post-MIS 10 period, sea level was rising fast (MurrayWallace and Woodroffe, 2014). The sedimentary architecture of the amalgamated channel deposits of the LG unit seems compatible with the ca. 335 to $325 \mathrm{ka}$ age estimate, as it suggests a coarse bedload river with high sediment supply.

The lower and middle parts of the US unit, comprising alternations of clayey silts, sands and palaeosols on clays to the east (flood-plain deposits) and dominant sand deposits to the west (channel belt), have a probable age of ca. 325 to $200 \mathrm{ka}$. This suggests formation during a period spanning MIS 9 through to MIS 7
(Fig. 17). This time period was characterized by: (i) high to medium sea levels (Murray-Wallace and Woodroffe, 2014); (ii) warm to mild climatic conditions (the interstadials of the MIS 7 were similar to the present Mediterranean climate) intercalated with a cold period during the late part of the MIS 8 (Roucoux et al., 2006; White et al., in press).

The sandy upper part of the US unit, with a probable age of 200 to $155 \mathrm{ka}$, seems to relate to the early part of MIS6 (Fig. 17). In this period, climate deterioration and a relative depletion of vegetation cover would have allowed enhanced sediment production in the catchment, while progressive sea-level lowering increased the longitudinal valley slope. This would have resulted in down-valley progradation of coarse grained fluvial deposits along the Tejo valley. Within the study area this is recorded by the covering of the fine-grained floodplain deposits by the sandy deposits of the upper part of the US unit.

The $\mathrm{T} 5$ terrace, located immediately below the T4, represents the MIS 5 in reach IV, and is correlated with the same terrace level in the upstream reaches of the Lower Tejo (ca. 135 to $75 \mathrm{ka}$ ). This time period was characterized by high to medium sea-levels (Fig. 17) and warm to mild climatic conditions (Salgueiro et al., 2010). 

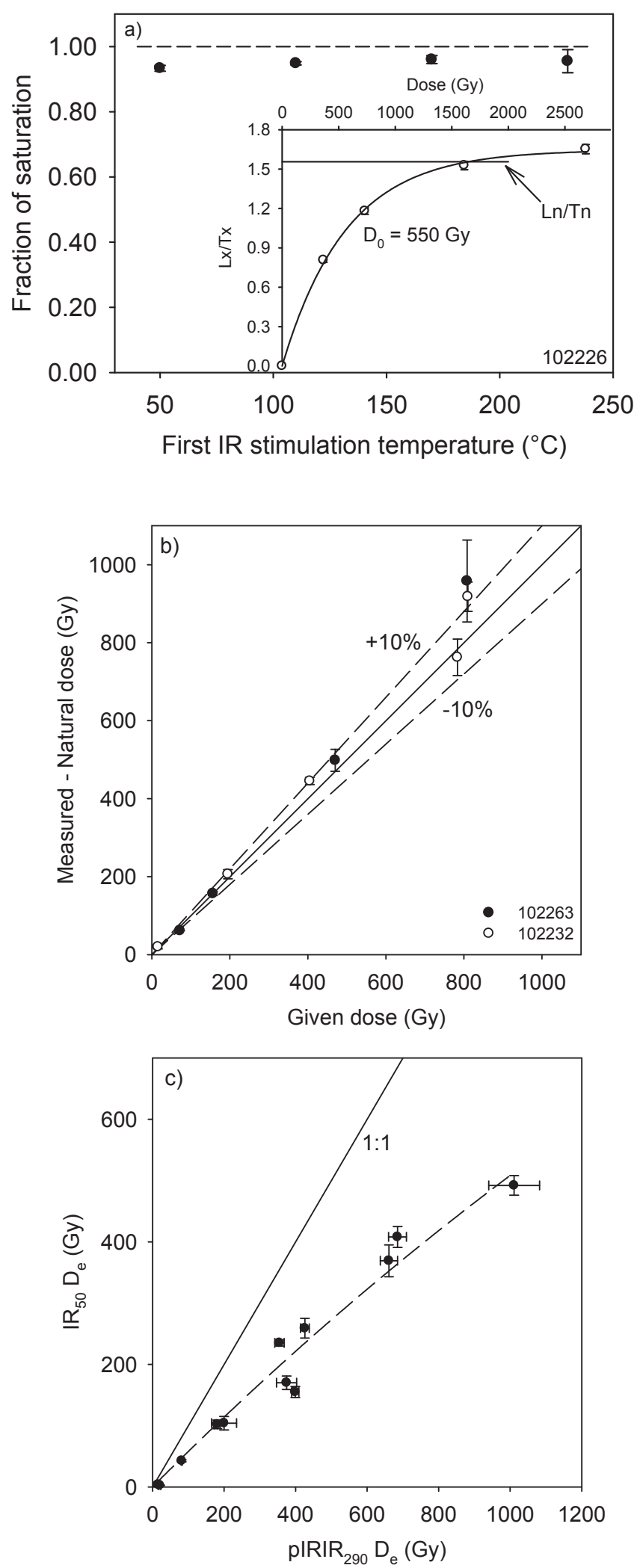

Fig. 15. a) First IR stimulation plateau for sample 102226. The natural signals are expressed as a fraction of the saturation level of the dose response curve. Three aliquots were measured per temperature and error bars represent one standard error. The inset shows the sensitivity corrected natural pIRIR290 signal (horizontal solid line) interpolated on the dose response curve for one aliquot measured using a first IR stimulation temperature of $50{ }^{\circ} \mathrm{C}$. b) Results of the dose recovery measurements. At least three aliquots were measured per data point and error bars represent one standard error. c) IR50 De values plotted as a function of the pIRIR290 De values for
The Carregueira Formation is an aeolian sand unit represented in several reaches of the Lower Tejo valley and can be related to the cold and dry climatic conditions that occurred between ca. 32 and $12 \mathrm{ka}$, during the Last Glacial period (MIS 2; Roucoux et al., 2005; Martins et al., 2010b; Cunha et al., 2012) (Fig. 17).

Additional palaeoenvironmental interpretations concerning the genesis of $\mathrm{T} 4$ can be made using the palaeosols that occur interbedded in the clays at the top of the middle part of US unit (Figs. 9 and 17). Their position, just above the VF8 archaeological level and below the level of the VForno8-2 sample, suggests a period spanning ca. 300 to $200 \mathrm{ka}$. The mottles and concretions within these soils, together with the presence of well-developed pressure faces and slickensides in the more clay rich horizons, suggest that the soils were subject to alternating wetting-drying cycles (Pal et al., 2009; Vepraskas and Lindbo, 2012). This hydromorphic interpretation is compatible with the position of soils within a fine-grained floodplain setting where the water table is close to the surface. Nevertheless, the variation of soil humidity suggests a strong seasonal variability in the floodplain, with waterlogged conditions presumably related to winter rain and flooding, and drying-up during the summer. Such a hydrological regime, typical of the Mediterranean climate, is consistent with palynological data from offshore Portugal (Roucoux et al., 2006), where forest expansions with a significant contribution from the Mediterranean floral elements were recorded during the three warm sub-stages MIS 7a, 7c, and 7e, that occurred between 243 and $185 \mathrm{ka}$ (Fig. 17).

Each palaeosol represents a hiatus in the alluvial sequence and indicates a period of floodplain stability. Forest expansion in MIS7 warm sub-stages would be favourable to lower sedimentation rates in the alluvial plain, with deposition dominated by fines, and palaeosol development. In turn, the cold and dry sub-stages with pronounced contraction of tree populations would be favourable to slope erosion and increased sedimentation rates on the alluvial plain, with deposition dominated by sands. The minimum time for formation of each palaeosol is thought to be of the order of $10^{3}-10^{4}$ years (Yaalon, 1983), consistent with the duration of sub-stages. A future stratigraphically-based detailed sampling for absolute dating could address this topic.

Previous studies in the Alpiarça area linked the T4 US unit to the Late Riss to Early Würm period of the Alpine chronology (i.e. ca. 150 to $70 \mathrm{ka}$ ). This chronology was mainly based on the technical and typological refinement of the VF3 site industry and on the TL minimum ages then obtained (Raposo, 1995a,b; Mozzi et al., 2000). Additionally, chronological constraints were also based on local and regional geomorphological considerations. However, the new luminescence ages presented within this study suggests the basal and middle parts of the US unit, containing the Middle and Late Acheulian VF1 and VF8 sites, are likely to be much older, ca. 325 to $200 \mathrm{ka}$.

The lithic industry of the VF3 site should not be considered as belonging to the alluvial sequence of the T4 terrace, as already discussed by Raposo (1996). The VF3 artefacts were worked on the T4 surface and were later covered by a colluvium and aeolian sands. If this colluvium can be ascribed to the base of the Carregueira Formation, with an age of 32 to $12 \mathrm{ka}$ and containing in situ Late Palaeolithic artefacts (Cunha et al., 2012), the VF3 industry should be younger than ca. $155 \mathrm{ka}$ but much older than $32 \mathrm{ka}$. Based on the typology of the handaxes, the age of this industry could not be much younger than $155 \mathrm{ka}$.

In the Middle and Upper Tejo/Tajo (in Spain) a maximum of 16 "true" fluvial terraces (not considering fan-head trench terraces)

samples for which the pIRIR290 De is $\leq 2 x D 0$ (see Table 4); error bars represent one standard error. The dashed line is the best fit through the data points. 
Table 3

Burial depth, Radionuclide activities $\left({ }^{238} \mathrm{U},{ }^{226} \mathrm{Ra},{ }^{232} \mathrm{Th}\right.$ and $\left.{ }^{40} \mathrm{~K}\right)$ and water content used for dose rate calculations of the luminescence dating samples.

\begin{tabular}{|c|c|c|c|c|c|c|c|}
\hline Sample code & Field code & Burial depth $(\mathrm{cm})$ & $\mathrm{U}-238\left(\mathrm{~Bq} \mathrm{~kg}^{-1}\right)$ & $\mathrm{Ra}-226\left(\mathrm{~Bq} \mathrm{~kg}^{-1}\right)$ & Th-232 (Bq kg $\left.{ }^{-1}\right)$ & $\mathrm{K}-40\left(\mathrm{~Bq} \mathrm{~kg}^{-1}\right)$ & Water content (\%) \\
\hline 132201 & Almer 1 & 80 & $12 \pm 4$ & $17.4 \pm 0.4$ & $22.8 \pm 0.5$ & $808 \pm 14$ & 5 \\
\hline 072226 & Azinh-3 & 60 & $49 \pm 8$ & $34.1 \pm 0.7$ & $46.5 \pm 0.8$ & $853 \pm 17$ & 15 \\
\hline 102233 & SATojal-1 & 1500 & $55 \pm 10$ & $44.2 \pm 0.9$ & $71.3 \pm 1.1$ & $710 \pm 16$ & 9 \\
\hline 102272 & Atojal-2 & 2500 & $18 \pm 3$ & $21.2 \pm 0.3$ & $32.9 \pm 0.4$ & $368 \pm 8$ & 25 \\
\hline 102231 & PSabug-2 & 145 & $41 \pm 6$ & $40.2 \pm 0.7$ & $61.3 \pm 0.8$ & $875 \pm 19$ & 18 \\
\hline PC5239 & Muge-1 & 60 & $30 \pm 6$ & $20.2 \pm 0.5$ & $23.0 \pm 0.5$ & $989 \pm 18$ & 10 \\
\hline PC5240 & Muge-2 & 100 & $14 \pm 3$ & $14.0 \pm 0.3$ & $18.3 \pm 0.3$ & $806 \pm 14$ & 11 \\
\hline 132245 & VForno-2 & 50 & $14 \pm 6$ & $12.2 \pm 0.5$ & $14.2 \pm 0.5$ & $1022 \pm 20$ & 5 \\
\hline 132244 & VForno-1 & 100 & $14 \pm 6$ & $17.5 \pm 0.5$ & $22.3 \pm 0.6$ & $964 \pm 18$ & 12 \\
\hline 072257 & VForno8-2 & 300 & $61 \pm 8$ & $56.6 \pm 0.9$ & $63.6 \pm 1.0$ & $829 \pm 17$ & 15 \\
\hline 052216 & AM-15 & 400 & $13 \pm 4$ & $16.4 \pm 0.6$ & $20.0 \pm 0.6$ & $1054 \pm 21$ & 22 \\
\hline 052222 & AM-21 & 275 & $24 \pm 6$ & $19.9 \pm 1.0$ & $24.6 \pm 0.9$ & $800 \pm 29$ & 26 \\
\hline 052223 & AM-22 & 375 & $20 \pm 4$ & $19.6 \pm 0.5$ & $14.3 \pm 0.4$ & $873 \pm 15$ & 22 \\
\hline 132246 & VCaval-1 & 500 & $17 \pm 7$ & $21.2 \pm 0.6$ & $32.6 \pm 0.7$ & $1003 \pm 20$ & 8 \\
\hline 132202 & Atela-2 & 250 & $26 \pm 6$ & $25.4 \pm 0.5$ & $30.4 \pm 0.6$ & $907 \pm 17$ & 11 \\
\hline 132203 & Atela-3 & $>1100$ & $28 \pm 6$ & $18.6 \pm 0.5$ & $17.5 \pm 0.6$ & $962 \pm 19$ & 10 \\
\hline 102226 & VgPeso-1 & 700 & $18 \pm 7$ & $13.8 \pm 0.5$ & $21.8 \pm 0.6$ & $798 \pm 16$ & 10 \\
\hline 102263 & Ptmuge & 30 & $21 \pm 3$ & $24.5 \pm 0.3$ & $28.8 \pm 0.4$ & $1125 \pm 17$ & 20 \\
\hline 102232 & Psabug-3 & 5 & $28 \pm 7$ & $22.7 \pm 0.6$ & $22.6 \pm 0.6$ & $1104 \pm 21$ & 28 \\
\hline
\end{tabular}

Table 4

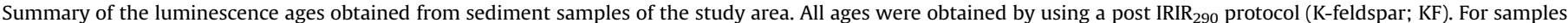

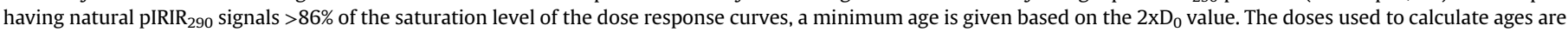

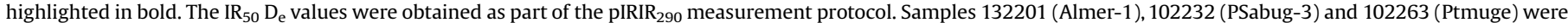
also measured using standard large aliquot quartz SAR-OSL (Q)

\begin{tabular}{|c|c|c|c|c|c|c|c|c|c|}
\hline Site & $\begin{array}{l}\text { NLL and field } \\
\text { code }\end{array}$ & $\begin{array}{l}\text { Altitude } \\
(\mathrm{m})\end{array}$ & $\begin{array}{l}\text { Lithology and Lithostratigraphic } \\
\text { unit }\end{array}$ & $\begin{array}{l}\mathrm{IR}_{50} \mathrm{D}_{\mathrm{e}} \\
(\mathrm{Gy})\end{array}$ & $\mathrm{pIRIR}_{290} \mathrm{D}_{\mathrm{e}}(\mathrm{Gy})$ & $\begin{array}{l}\mathrm{pIRIR}_{290} 2^{*} \mathrm{Do} \\
(\mathrm{Gy})\end{array}$ & $\begin{array}{l}\text { Dose rate }(\mathrm{Gy} / \\
\text { ka) }\end{array}$ & $\mathrm{n}$ & Age (ka) \\
\hline Almeirim & $\begin{array}{l}132201 \\
\text { Almer-1 }\end{array}$ & 22 & $\begin{array}{l}\text { Aeolian medium sand } \\
\text { Carregueira formation }\end{array}$ & $42.6 \pm 1.5$ & $\begin{array}{l}60.7 \pm 1.9(\mathbf{Q}) \\
81.6 \pm 1.7(F K)\end{array}$ & - & $\begin{array}{l}3.18 \pm 0.14(\mathrm{Q}) \\
4.00 \pm 0.15(\mathrm{FK})\end{array}$ & $\begin{array}{l}12(\mathrm{Q}) \\
6(\mathrm{FK})\end{array}$ & $\begin{array}{l}19.1 \pm 1.1(\mathrm{Q}) \\
20.4 \pm 1.1(\mathrm{FK})\end{array}$ \\
\hline Azinhaga & $\begin{array}{l}072226 \\
\text { Azinh-3 }\end{array}$ & 16.4 & $\begin{array}{l}\text { Pebbly coarse sand } \\
\text { T6 (top) }\end{array}$ & $102 \pm 7$ & $181 \pm 8$ & - & $4.64 \pm 0.16$ & 18 & $39 \pm 2$ \\
\hline $\begin{array}{l}\text { Sto. Antão do } \\
\text { Tojal }\end{array}$ & $\begin{array}{l}102233 \\
\text { SATojal-1 }\end{array}$ & 6.5 & $\begin{array}{l}\text { Medium sand } \\
\text { T5 (top) }\end{array}$ & $155 \pm 9$ & $399 \pm 10$ & - & $4.93 \pm 0.19$ & 12 & $81 \pm 4$ \\
\hline $\begin{array}{l}\text { Sto. Antão do } \\
\text { Tojal }\end{array}$ & $\begin{array}{l}102272 \\
\text { Atojal-2 }\end{array}$ & 5.5 & $\begin{array}{l}\text { Silty clay } \\
\text { T5 (top) }\end{array}$ & $104 \pm 11$ & $200 \pm 35$ & - & $2.66 \pm 0.10$ & 6 & $75 \pm 14$ \\
\hline Porto Sabugueiro & $\begin{array}{l}102231 \\
\text { PSabug-2 }\end{array}$ & 9.0 & $\begin{array}{l}\text { Coarse sand } \\
\text { T5 (top) }\end{array}$ & $170 \pm 11$ & $375 \pm 28$ & - & $5.03 \pm 0.18$ & 6 & $75 \pm 6$ \\
\hline Rib. Muge & $\begin{array}{l}\text { PC5239 } \\
\text { Muge-1 }\end{array}$ & 13 & $\begin{array}{l}\text { Medium to fine sand } \\
\text { T5 (top) }\end{array}$ & $259 \pm 16$ & $426 \pm 12$ & $846 \pm 66$ & $4.57 \pm 0.20$ & 9 & $93 \pm 5$ \\
\hline Rib. Muge & $\begin{array}{l}\text { PC5240 } \\
\text { Muge-2 }\end{array}$ & 12.6 & $\begin{array}{l}\text { Medium to fine sand } \\
\text { T5 (top) }\end{array}$ & $235 \pm 5$ & $355 \pm 13$ & $838 \pm 14$ & $3.81 \pm 0.16$ & 6 & $93 \pm 5$ \\
\hline Vale do Forno & $\begin{array}{l}132245 \\
\text { VForno-2 }\end{array}$ & 33.5 & $\begin{array}{l}\text { Medium sand } \\
\text { T4 (US topmost) }\end{array}$ & $410 \pm 20$ & $685 \pm 25$ & $861 \pm 14$ & $4.44 \pm 0.20$ & 3 & $154 \pm 10$ \\
\hline Vale do Forno & $\begin{array}{l}132244 \\
\text { VForno-1 }\end{array}$ & 33 & $\begin{array}{l}\text { Medium sand } \\
\text { T4 (US topmost) }\end{array}$ & $370 \pm 30$ & $661 \pm 24$ & $1042 \pm 25$ & $4.19 \pm 0.18$ & 6 & $158 \pm 9$ \\
\hline Vale do Forno & $\begin{array}{l}072257 \\
\text { VForno8-2 }\end{array}$ & 31 & $\begin{array}{l}\text { Fine sand } \\
\text { T4 (US middle) }\end{array}$ & $490 \pm 20$ & $1011 \pm 71$ & $1022 \pm 55$ & $5.03 \pm 0.18$ & 3 & $201 \pm 16$ \\
\hline Vale do Forno & $\begin{array}{l}052216 \\
\text { AM-15 }\end{array}$ & 15 & $\begin{array}{l}\text { Coarse sand } \\
\text { T4 (US base) }\end{array}$ & - & $1130 \pm 90$ & $963 \pm 10$ & $3.64 \pm 0.13$ & 3 & $>270$ \\
\hline $\begin{array}{l}\text { Quinta dos } \\
\text { Patudos }\end{array}$ & $\begin{array}{l}052222 \\
\text { AM-21 }\end{array}$ & 34 & $\begin{array}{l}\text { Coarse sand } \\
\text { T4 (US middle) }\end{array}$ & - & $1330 \pm 270$ & $1048 \pm 45$ & $3.53 \pm 0.12$ & 3 & $>300$ \\
\hline Fonte da Burra & $\begin{array}{l}052223 \\
A M-22\end{array}$ & 5.0 & $\begin{array}{l}\text { Coarse sand } \\
\text { T4 (US base) }\end{array}$ & - & $1180 \pm 50$ & $984 \pm 42$ & $3.64 \pm 0.12$ & 3 & $>270$ \\
\hline Vale de Cavalos & $\begin{array}{l}132246 \\
\text { VCaval-1 }\end{array}$ & 23 & $\begin{array}{l}\text { Medium sand } \\
\text { T4 (US base) }\end{array}$ & - & $1700 \pm 60$ & $926 \pm 15$ & $4.59 \pm 0.21$ & 2 & $>200$ \\
\hline Vale de Atela & $\begin{array}{l}132202 \\
\text { Atela-2 }\end{array}$ & 33 & $\begin{array}{l}\text { Medium sand } \\
\text { T4 (US top) }\end{array}$ & - & $1170 \pm 70$ & $784 \pm 20$ & $4.29 \pm 0.18$ & 3 & $>200$ \\
\hline Vale de Atela & $\begin{array}{l}132203 \\
\text { Atela-3 }\end{array}$ & 19 & $\begin{array}{l}\text { Pebbly medium sand } \\
\text { T4 (LG middle) }\end{array}$ & - & $1500 \pm 290$ & $879 \pm 37$ & $4.00 \pm 0.18$ & 3 & $>200$ \\
\hline V. geodésico Peso & $\begin{array}{l}102226 \\
\text { Vg Peso } 1\end{array}$ & 71 & $\begin{array}{l}\text { Gravelly coarse sand } \\
\mathrm{T} 1\end{array}$ & - & $1600 \pm 50$ & $1170 \pm 40$ & $3.85 \pm 0.14$ & 3 & $>304$ \\
\hline Porto de Muge & $\begin{array}{l}102263 \\
\text { Ptmuge }\end{array}$ & 3.0 & $\begin{array}{l}\text { Medium sand } \\
\text { Modern river bed }\end{array}$ & $3.6 \pm 1.1$ & $\begin{array}{l}0.81 \pm 0.14(Q) \\
15.36 \pm 1.02 \\
(F K)\end{array}$ & - & $\begin{array}{l}3.85 \pm 0.15(\mathrm{Q}) \\
4.62 \pm 0.16(\mathrm{FK})\end{array}$ & $\begin{array}{l}12(\mathrm{Q}) \\
15 \\
(\mathrm{FK})\end{array}$ & $\begin{array}{l}0.21 \pm 0.04(\mathrm{Q}) \\
3.32 \pm 0.26 \\
(\mathrm{FK})\end{array}$ \\
\hline Porto Sabugueiro & $\begin{array}{l}102232 \\
\text { PSabug-3 }\end{array}$ & 4.0 & $\begin{array}{l}\text { Coarse sand } \\
\text { Modern river bed }\end{array}$ & $2.7 \pm 0.3$ & $\begin{array}{l}0.57 \pm 0.12(Q) \\
20.5 \pm 2.5(F K)\end{array}$ & - & $\begin{array}{l}3.52 \pm 0.13(\mathrm{Q}) \\
4.24 \pm 0.14(\mathrm{FK})\end{array}$ & $\begin{array}{l}34(\mathrm{Q}) \\
6(\mathrm{FK})\end{array}$ & $\begin{array}{l}0.16 \pm 0.03(\mathrm{Q}) \\
4.83 \pm 0.63 \\
(\mathrm{FK})\end{array}$ \\
\hline
\end{tabular}




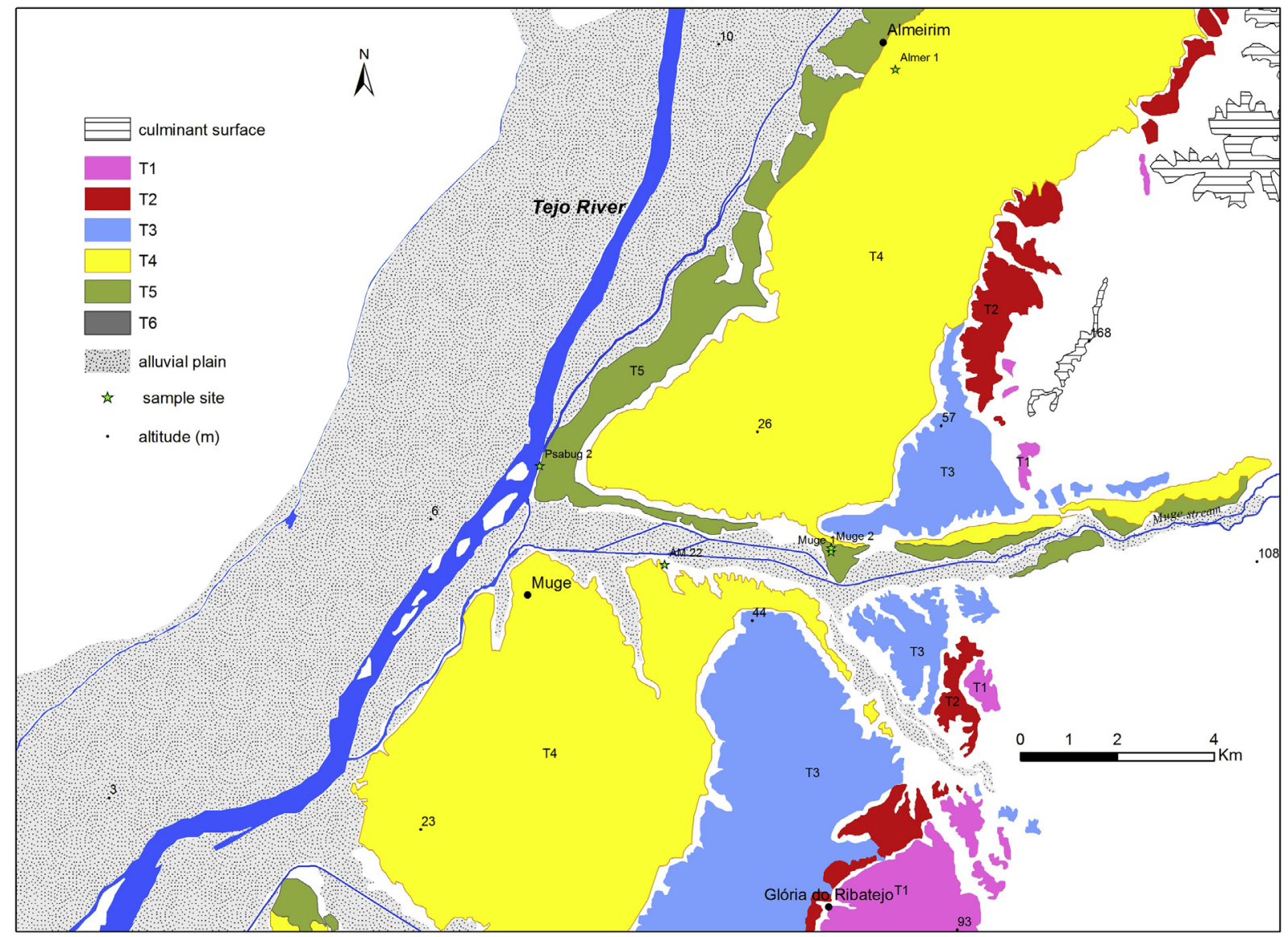

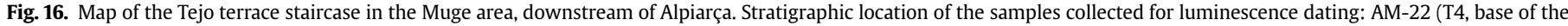
US unit); PSabug-2 (T5 top); Muge-1 and Muge-2 (T5 top); Almer-1 (Carregueira Formation; aeolian cover sands, not mapped in this figure).

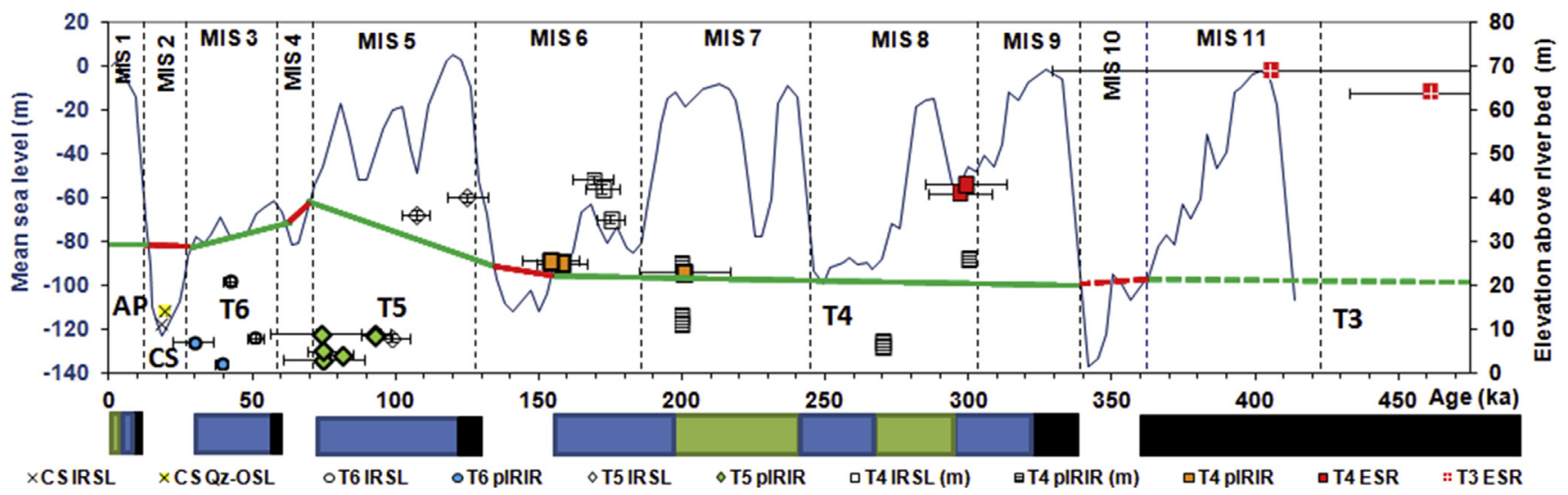

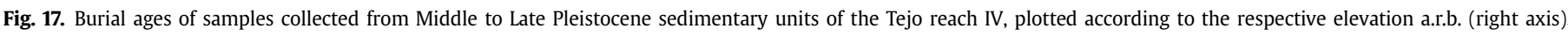

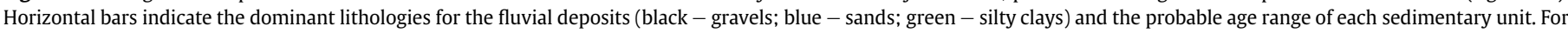

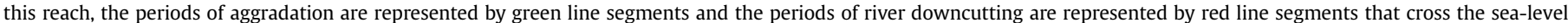

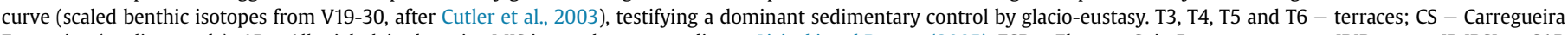

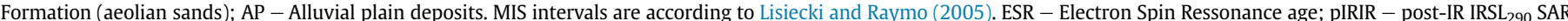

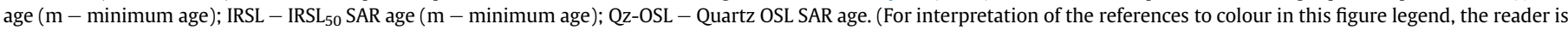
referred to the web version of this article.)

have been identified and dated by combining absolute ages and paleomagnetic data (Silva et al., 2016): (i) the first Palaeolithic materials are represented by isolated large flint flakes of apparent early Achaeulian fracture, and these are associated with the $+100-107 \mathrm{~m}$ to $+80-85 \mathrm{~m}$ terraces (probably with ages ca.
1.4-1.2 Ma); (ii) Achaeulian sites were found in terraces ranging from +70 to $78 \mathrm{~m}$ (probably ca. $1.1-1.0 \mathrm{Ma}$ ) to $+18-22 \mathrm{~m}$ (ca. 135 to $74 \mathrm{ka}$ ), the later terrace has upper stratigraphic levels containing Middle Palaeolithic industry with Mousterian knapping technology; (iii) Mousterian sites were found in terraces between +15 and 
$13 \mathrm{~m}$ to $+8-10 \mathrm{~m}$ (ca. 60 to $28 \mathrm{ka}$ ) (e.g. Santonja and PérezGonzález, 2010; Pérez-González et al., 2013; Panera et al., 2014; López-Recio et al., 2015; Roquero et al., 2015a, 2015b; Rubio-Jara et al., 2016). The most complete list of artefacts associated with a warm faunal assemblage was found in the Achaeulian sites of Pinedo and Cien Fanegas (Tagus valley, near Toledo) in the $+25-30$ m terrace, with top deposits dated as $226 \pm 37 \mathrm{ka}$ (by Amino-Acid Racemization) and the base deposits dated as $>280 \mathrm{ka}$ and $292 \pm 17 \mathrm{ka}$ (pIR-IRSL) (López-Recio et al., 2013, 2015). So, this terrace of the Middle Tejo correlates well with the Lower Tejo T4 terrace.

However, there are not enough reliable and precise absolute ages to support a detailed correlation between the staircases of the Middle and Upper Tejo/Tajo (in Spain, up to 16 fluvial terrace levels) and the Lower Tejo (in Portugal, only 6 terrace levels). We should also note that the sedimentary controls for the formation of the Lower Tejo staircases are different (mainly glacio-eustasy and differential uplift) and that the Lower Tejo is separated from the Middle and Upper Tejo by a large permanent knick zone of hard basement (Cunha et al., 2016; Silva et al., 2016). The ages already obtained from the terraces of the lower reach of the Portuguese Mondego River (Ramos et al., 2012) seem to correlate well with the Lower Tejo River terraces; both of the river reaches seem to have glacio-eustatic control on their development.

\section{Conclusions}

Geomorphological analysis of the Lower Tejo reach IV confirms the existence of six sedimentary terrace levels, discontinuously represented along the entire of the Lower Tejo valley. In the upstream reaches I and III, six terrace levels have already been recognized by previous workers. Longitudinal correlation between these terraces indicates that a graded profile ca. $200 \mathrm{~km}$ long was achieved during terrace formation periods and a strong control by marine base level was a key determinant for terrace formation.

In the study area, the sedimentary units of the T4 terrace seem to record the fluvial response to sea-level changes and climaticallydriven fluctuations in sediment supply.

The thick, coarse and dominantly massive gravels of the LG unit indicate deposition by a coarse bed-load braided river, with strong sediment supply, high gradient and fluvial competence, during conditions of rapidly rising sea level. Luminescence dating only provided minimum ages but it is probable that the LG unit corresponds to the earlier part of the MIS 9 (337-325 ka), immediately postdating the incision promoted by the very low sea level (reaching ca. $-140 \mathrm{~m}$ ) during MIS $10(362-337 \mathrm{ka})$, a period of relatively cold climate conditions with weak vegetation cover on slopes and low sea level.

The lower and middle parts of the US unit, comprising an alternation of clayish silts with palaeosols and minor sands to the east (flood-plain deposits) and sand deposits to the west (channel belt), have a probable age of ca. 325 to $200 \mathrm{ka}$. This suggests formation during MIS 9 to MIS 7, under conditions of warm to cold conditions and a high to medium sea level.

The upper part of the US unit, dominated by sand facies and with an age of ca. 200 to $155 \mathrm{ka}$, correlates with the early part of the MIS 6. During this period, fluvial aggradation and progradation resulted from climate deterioration and relative depletion of vegetation that promoted enhanced sediment production in the catchment, coupled with initiation of sea-level lowering that increased the longitudinal slope.

The oldest artefacts previously found in the LG unit, display crude bifacial forms that can be attributed to the Acheulian, with a probable age of ca. 335 to $325 \mathrm{ka}$.

The VF1 and VF8 Acheulian industries, situated in the T4 US unit, probably date 325 to 300 ka. Notably, these Lower Palaeolithic artisans were able to produce tools with different levels of sophistication, simply by applying different strategies. More elaborated reduction sequences were used in case of bifaces, and simpler reduction sequences to obtain cleavers.

The VF3 artefacts were abandoned on the T4 surface and later covered by a colluvium and aeolian sands. This industry is younger than ca. 155 ka but much older than $32 \mathrm{ka}$; we consider that the VF3 industry should be interpreted as representing an occupation on the T4 surface shortly after the end of deposition.

The differences observed in the lithic assemblages documented at each of these sites can be attributed to a certain degree to particular economic functionalities. But, simultaneously, taking into account the stratigraphic position of these sites and the global technological and typological characteristics of the most relevant tools types (bifaces, cleavers, side-scrapers) we are also impelled to consider the occurrence of local evolutionary chronological trends. More data is still needed, however, not only to narrowly establish the age of each site, but also to relate this local sequence to others, at the regional level. This will hopefully allow the development of a new and more complete technological framework.

\section{Acknowledgements}

This study was supported by the Fundação para a Ciência e a Tecnologia, through projects PTDC/GEO-GEO/2860/2012 (FASTLOAD), UID/MAR/04292/2013 - MARE and UID/GEO/04683/2013 ICT. The authors wish to thank David Bridgland and an anonymous reviewer for the very constructive comments and suggestions that greatly improved the manuscript.

\section{References}

Aslan, A., Autin, W.J., 1998. Holocene flood-plain soil formation in the southern lower Mississippi Valley: implications for interpreting alluvial paleosols. Bull. Geol. Soc. Am. 110, 433-449.

Barbosa, B.P., 1995. Alostratigrafia e Litostratigrafia das unidades continentais da Bacia Terciária do Baixo Tejo. Relações com o eustatismo e a tectónica. PhD Thesis. Univ. Lisboa, p. 253.

Bensaúde, A., 1910. Le tremblement de terre de la vallée du Tage du 23 avril 1909 (Note préliminaire). Bull. Soc. Port. Sc. Nat. III 89-129.

Besana-Ostman, G.M., Villanova, S.P., Nemser, E.S., Falcão Flor, A.P., Heleno, S., Ferreira, H., Fonseca, J.D., 2012. Large Holocene earthquakes in the lower Tagus valley fault zone, Central Portugal. Seismol. Res. Lett. 83 (1), 67-76. http:// dx.doi.org/10.1785/gssrl.83.1.67.

Blum, M.D., Törnqvist, T.E., 2000. Fluvial responses to climate and sea-level change; a review and look forward. Sedimentology 47 (Suppl. 1), 2-48.

Breuil, H., Zbyszewski, G., 1942. Contribution à l'étude des industries Paléolithiques du Portugal et de leurs rapports avec la géologie du Quaternaire. Les principaux gisements des deux rivers de l'ancien estuaire du Tage. Comunicações dos Serviços Geológicos de Portugal XXIII, Lisboa, p. 369.

Breuil, H., Zbyszewski, G., 1945. Contribution à létude des industries Paléolithiques du Portugal et de leurs rapports avec la géologie du Quaternaire. Les principaux gisements des plages quaternaires du littoral dÉstremadura et des terrasses fluviales de la basse vallée du Tage. Comunicações dos Serviços Geológicos de Portugal XXVI, Lisboa, p. 662.

Bridgland, D.R., Westaway, R., 2008. Climatically controlled river terrace staircases: a worldwide Quaternary phenomenon. Geomorphology 98, 285-315.

Bridgland, D.R., Westaway, R., 2014. Quaternary fluvial archives and landscape evolution: a global synthesis. Proc. Geol. Assoc. 125, 600-629.

Bridgland, D.R., White, M.J., 2014. Fluvial archives as a framework for the Lower and Middle Palaeolithic: patterns of British artefact distribution and potential chronological implications. Boreas 43, 543-555.

Bridgland, D.R., White, M.J., 2015. Chronological variations in handaxes: patterns detected from fluvial archives in NW Europe. J. Ouat. Sci. 30, 623-638.

Bridgland, D.R., Antoine, P., Limondin-Lozouet, N., Santisteban, J.I., Westaway, R., White, M.J., 2006. The Palaeolithic occupation of Europe as revealed by evidence from the rivers: data from IGCP 449. J. Quat. Sci. 21, 437-455.

Bull, W.B., 2009. Geomorphic Responses to Climatic Change. Blackburn Press, p. 328.

Buylaert, J.P., Murray, A.S., Thomsen, K.J., Jain, M., 2009. Testing the potential of an elevated temperature IRSL signal from K-feldspar. Radiat. Meas. 44, 560-565.

Buylaert, J.-P., Jain, M., Murray, A.S., Thomsen, K.J., Thiel, C., Sohbati, R., 2012. A robust feldspar luminescence dating method for Middle and Late Pleistocene sediments. Boreas 41, 435-451. 
Buylaert, J.-P., Murray, A.S., Gebhardt, A.C., Sohbati, R., Ohlendorf, C., Thiel, C., Wastegård, S., Zolitschka, B., The PASADO Science Team, 2013. Luminescence dating of the PASADO core 5022-1D from Laguna Potrok Aike (Argentina) using IRSL signals from feldspar. Quat. Sci. Rev. 71, 70-80.

Cabral, J., 1995. Neotectónica de Portugal continental, vol. 31. Memórias do Instituto Geológico e Mineiro, Portugal, p. 265.

Cabral, J., 2012. Neotectonics of mainland Portugal: state of the art and future perspectives. J. Iber. Geol. 38 (1), 71-84.

Cabral, J., Ribeiro, A., 1988. Carta Neotectónica de Portugal Continental, Escala 1: 1.000.000. Serv. Geol. de Portugal, Lisboa.

Cabral, J., Ribeiro, A., 1989. Carta Neotectónica de Portugal Continental, Escala 1: 1.000.000. Nota explicativa. Serv. Geol. Portugal, Lisboa, p. 10.

Cabral, J., Moniz, C., Ribeiro, P., Terrinha, P., Matias, L., 2003. Analysis of seismic reflection data as a tool for the seismotectonic assessment of a low activity intraplate basin - the Lower Tagus Valley (Portugal). J. Seismol. 7, 431-447. http://dx.doi.org/10.1023/B:JOSE.0000005722.23106.8d.

Cabral, J., Ribeiro, P., Figueiredo, P., Pimentel, N., Martins, A., 2004. The Azambuja fault: an active structure located in an intraplate basin with significant seismicity (Lower Tagus Valley, Portugal). J. Seismol. 8, 347-362.

Cabral, J., Moniz, C., Batló, J., Figueiredo, P., Carvalho, J., Matias, L., Teves-Costa, P., Dias, R., Simão, N., 2013. The 1909 Benavente (Portugal) earthquake: search for the source. Nat. Hazards 69, 1211-1227. http://dx.doi.org/10.1007/s11069-0110062-8.

Carvalho, J., Rabeh, T., Cabral, J., Carrilho, F., Miranda, J.M., 2008. Geophysical characterization of the Ota-Vila Franca de Xira-Lisbon-Sesimbra fault zone. Port. Geophys. J. Int. 174, 567-584. http://dx.doi.org/10.1111/j.1365246X.2008.03791.X.

Carvalho, J., Rabeh, T., Dias, R., Dias, R., Pinto, C., Oliveira, T., Cunha, T., Borges, J., 2014. Tectonic and neotectonic implications of a new basement map of the Lower Tagus Valley, Portugal. Tectonophysics 617, 88-100.

Chauhan, P., Bridgland, D., Moncel, M.-H., Antoine, P., Bahain, J.-J., Briant, R. Cunha, P.P., Locht, J.-L., Martins, A., Schreve, D., Shaw, A., Voinchet, P., Westaway, R., White, M., White, T., 2016. Fluvial deposits as an archive of early human activity: progress during the 20 years of the Fluvial Archives Group. Quat. Sci. Rev. Special Issue - Fluvial Archives Group, JQSR-D-16-00195.

Choffat, P., 1907. Notice sur la Carte Hypsométrique du Portugal. Com. Serv. Geol. Port. VII $1-71$

Corral, I., 1998a. Depositos Cuaternarios en el área de Constância-BarquinhaEntroncamento y la Rib. del Bezelga. In: Cruz, A.R., Oosterbeek, L., Reis, R.P. (Eds.), Arkeos 4, Quaternário e Pré-História do Alto Ribatejo (Portugal), CEIPHAR, pp. 59-144.

Corral, I., 1998b. Secciones com material arqueológico en estrato en las proximidades de Atalaia. In: Cruz, A.R., Oosterbeek, L., Reis, R.P. (Eds.), Arkeos 4, Quaternário e Pré-História do Alto Ribatejo (Portugal), CEIPHAR, pp. 227-250.

Cunha, P.P., 1992. Estratigrafia e sedimentologia dos depósitos do Cretácico Superior e Terciário de Portugal Central, a leste de Coimbra. PhD thesis. Univ. Coimbra, Portugal, p. 262

Cunha, P.P., 1996. Unidades litostratigráficas do Terciário da Beira Baixa (Portugal), vol. 82. Comum. Instituto Geol. Mineiro, pp. 87-130.

Cunha, P.P., Barbosa, B.P., Pena dos Reis, R., 1993. Synthesis of the Piacenzian Onshore Record, between the Aveiro and Setúbal Parallels (Western Portuguese Margin), 12. Ciências da Terra (Univ. Nova de Lisboa), pp. 35-43.

Cunha, P.P., Martins, A.A., Daveau, S., Friend, P.F., 2005. Tectonic control of the Tejo river fluvial incision during the late Cenozoic, in Ródão - central Portugal (Atlantic Iberian border). Geomorphology 64, 271-298.

Cunha, P.P., Martins, A.A., Huot, S., Murray, A., Raposo, L., 2008. Dating the Tejo River lower terraces in the Ródão area (Portugal) to assess the role of tectonics and uplift. Geomorphology 102, 43-54.

Cunha, P.P., Almeida, N.A.C., Aubry, T., Martins, A.A., Murray, A.S., Buylaert, J.-P., Sohbati, R., Raposo, L., Rocha, L., 2012. Records of human occupation from Pleistocene river terrace and aeolian sediments in the Arneiro depression (Lower Tejo River, central eastern Portugal). Geomorphology 165-166, 78-90.

Cunha, P.P., Martins, A.A., Gouveia, M.P., 2016. The terrace staircases of the Lower Tagus River (Ródão to Chamusca) - characterization and interpretation of the sedimentary, tectonic, climatic and and Palaeolithic data. Quat. Stud. 14, 1-24. http://www.apeq.pt/ojs/index.php/apeq.

Cutler, K.B., Edwards, R.L., Taylor, F.W., Cheng, H., Adkins, J., Gallup, C.D., Cutler, P.M., Burr, G.S., Bloom, A.L., 2003. Rapid sea-level fall and deep-ocean temperature change since the last interglacial period. Earth Planet. Sci. Lett. 206, 253-271.

De Vicente, G., Cloetingh, S., Van Wees, J.D., Cunha, P.P., 2011. Tectonic classification of Cenozoic Iberian foreland basins. Tectonophysics $502(1-2), 38-61$. http:// dx.doi.org/10.1016/j.tecto.2011.02.007.

Diniz, F., Silva, C.M., Cachão, M., 2016. O Pliocénico de Pombal (Bacia do Mondego, Portugal oeste): biostratigrafia, Paleoecologia e Paleobiogeografia. Quat. Stud. 14, 41-59. http://www.apeq.pt/ojs/index.php/apeq.

Dinka, T.M., Morgan, C.L.S., McInnes, K.J., Kishné, A.S., Harmel, R.D., 2013. Shrink-swell behavior of soil across a Vertisol catena. J. Hydrol. 476, 352-359.

Douglass, J., Schmeeckle, M., 2007. Analogue modeling of transverse drainage mechanisms. Geomorphology 84 (1-2), 22-43. http://dx.doi.org/10.1016/ j.geomorph.2006.06.004.

Duller, G.A.T., 2004. Luminescence dating of Quaternary sediments: recent advances. J. Quat. Sci. 19, 183-192.

Freire de Andrade, C.B., 1933. A tectónica do estuário do Tejo e dos vales submarinos ao largo da costa da Caparica, e sua relação com as nascentes termo-medicinais de Lisboa. Com. Serv. Geol. Port. 19, 23-40.
Gibbard, P.L., Lewin, J., 2002. Climate and related controls on interglacial sedimentation in lowland Britan. Sediment. Geol. 151, 187-210.

Huggett, R.J., 1998. Soil chronosequences, soil development, and soil evolution: critical review. Catena 32, 155-172.

Huntley, D.J., Baril, M.R., 1997. The K content of the K-feldspars being measured in optical dating or in thermoluminescence dating. Anc. TL 15, 11-13.

Jahn, R., Blume, H.P., Asio, V.B., Spaargaren, O., Schad, P., Langohr, R., Brinkman, R. Nachtergaele, F.O., Pavel Krasilnikov, R., 2006. Guidelines for Soil Description. FAO, Rome, p. 97.

Lamothe, M., Auclair, M., Hamzaoui, C., Huot, S., 2003. Towards a prediction of longterm anomalous fading of feldspar IRSL. Radiat. Meas. 37, 493-498.

Lewis, S., Maddy, D., Glenday, S., 2004. The Thames Valley Sediment Conveyor: fluvial system development over the last two interglacial-glacial cycles. Quaternaire $15,17-28$.

Lisiecki, L.E., Raymo, M.E., 2005. A Pliocene-Pleistocene stack of 57 globally distributed benthic $\delta 180$ records. Paleoceanography 20 (1), 1-17. http:/| dx.doi.org/10.1029/2004PA001071.

López-Recio, M., Silva, P.G., Cunha, P.P., Tapias, F., Roquero, E., Morín, J., Carrobles, J. Murray, A.S., Buylaert, J.-P., 2013. Dataciones por luminiscencia de la terraza $+25-30$ m del río Tajo en la área de Toledo. El yacimiento Achelense de Pinedo. Proc. VIII Reunión Cuaternario Ibérico 17-21.

López-Recio, M., Silva, P.G., Roquero, E., Cunha, P.P., Tapias, F., Alcaraz-Castaño, M. Baena, J., Cuartero, F., Morín, J., Torres, T., Ortiz, J.E., Murray, A.S., Buylaert, J.P. 2015. Geocrolología de los yacimientos achelenses de Pinedo y Cien Fanegas (Valle del Tajo) e implicaciones en la evolución fluvial en el entorno de Toledo (España). Estud. Geol. 71 (1), 1-19.

Martins, A.A., 1999. Caracterização morfotectónica e morfossedimentar da Bacia do Baixo Tejo (Pliocénico e Quaternário). PhD Thesis. University of Évora, p. 500.

Martins, A.A., Cunha, P.P., Huot, S., Murray, A., Buylaert, J.-P., 2009. Geomorphological correlation of the tectonically displaced Tejo river terraces (GaviãoChamusca area, Portugal) supported by luminescence dating. Quat. Int. 199, 75-91.

Martins, A.A., Cunha, P.P., Buylaert, J.-P., Huot, S., Murray, A., Dinis, P., Stokes, M., 2010a. K-feldspar IRSL dating of a Pleistocene river terrace sequence of the Lower Tejo River (Portugal, western Iberia). Quat. Geochronol. 5, 176-180.

Martins, A.A., Cunha, P.P., Rosina, P., Osterbeek, L., Cura, S., Grimaldi, S., Gomes, J. Buylaert, J.-P., Murray, A., Matos, J., 2010b. Geoarchaeology of Pleistocene openair sites in the Vila Nova da Barquinha-Santa Cita area (Lower Tejo River basin, central Portugal). Proc. Geol. Assoc. 121, 128-140.

Merritts, J., Vicent, R., Wohl, E., 1994. Long river profiles, tectonism and eustasy: guide to interpreting fluvial terraces. J. Geophys. Res. 99 (B7), 14031-14050.

Montenegro de Andrade, M., 1944. Estudo polínico de algumas formações turfoinhitosas portuguesas. Publicações do Mus. Lab. Mineral. Geol. Fac. Ciências do Porto 37, 5-11.

Mozzi, P., Azevedo, T., Nunes, E., Raposo, L., 2000. Middle terrace deposits of the Tagus river in Alpiarça, Portugal, in relation to early human occupation. Quat. Res. 54, 359-371.

Murray, A.S., Wintle, A.G., 2000. Luminescence dating of quartz using an improved single-aliquot regenerative-dose protocol. Radiat. Meas. 32, 57-73.

Murray, A.S., Wintle, A.G., 2003. The single aliquot regenerative dose protocol potential for improvements in reliability. Radiat. Meas, 37, 377-381.

Murray, A., Marten, R., Johnston, A., Martin, P., 1987. Analysis for naturally occurring radionuclides at environmental concentrations by gamma spectrometry. . Radioanal. Nucl. Chem. 115, 263-288.

Murray, A.S., Thomsen, K.J., Masuda, N., Buylaert, J.-P., Jain, M., 2012. Identifying well-bleached quartz using the different bleaching rates of quartz and feldspar luminescence signals. Radiat. Meas. 47, 688-695.

Murray-Wallace, C.V., Woodroffe, C.D., 2014. Quaternary Sea-level Changes: a Global Perspective. Cambridge University Press, Cambridge, UK, p. 502.

Oliveira, J.T., Pereira, E., Ramalho, M., Antunes, M.T., Monteiro, J.H., Coord., 1992 Carta Geológica de Portugal à escala 1/500000, 5. Serviços Geológicos de Portugal, Lisboa.

Olley, J.M., Murray, A.S., Roberts, R.G., 1996. The effects of disequilibria in the uranium and thorium decay chains on burial dose rates in fluvial sediments. Quat. Sci. Rev. 15, 751-760.

Pais, J., Cunha, P.P., Pereira, D., Legoinha, P., Dias, R., Moura, D., Brum da Silveira, A., Kullberg, J.C., González-Delgado, J.A., 2012. The Paleogene and Neogene of Western Iberia (Portugal). A Cenozoic Record in the European Atlantic Domain. SpringerBriefs in Earth Sciences, Springer, p. 158. Series ID: 8897.

Pal, D.K., Bhattacharyya, T., Chandran, P., Ray, S.K., Satyavathi, P.L.A., Durge, S.L. Raja, P., Maurya, U.K., 2009. Vertisols (cracking clay soils) in a climosequence of Peninsular India: evidence for Holocene climate changes. Quat. Int. 209, 6-21.

Panera, J., Rubio-Jara, S., Yravedra, J., Hugues-Alexandre, B., Sesé, C., PérezGonzález, A., 2014. Manzanares Valley (Madrid, Spain): a good country for proboscideans and Neanderthals. Quat. Int. 326-327, 329-343.

Pérez-González, A., 1994. Depresión del Tajo. In: Gutiérrez-Elorza, M. (Ed.), Geomorfologia de España. Editorial Rueda, pp. 389-436.

Pérez-González, A., Gallardo-Millán, J.L., Uribelarrea del Val, D., Panera, J., Rubioara, S., 2013. La inversión Matuyama-Brunhes en la secuencia de terrazas del río Jarama entre Velilla de San Antonio y Altos de la Mejorada, al SE de Madrid (España). Estud. Geol. 69 (1), 35-46.

Ramos, A., Cunha, P.P., Cunha, L., Gomes, A., Lopes, F.C., Buylaert, J.-P., Murray, A.S. 2012. The River Mondego terraces at the Figueira da Foz coastal area (western central Portugal): geomorphological and sedimentological characterization of a terrace staircase affected by differential uplift and glacio-eustasy. 
Geomorphology 165-166, 107-123.

Raposo, L., 1995a. Ambientes, territórios y subsistência en el Paleolítico Médio de Portugal. Complutum 6, 57-77.

Raposo, L., 1995b. O paleolítico. In: Medina, J. (Ed.), História de Portugal, vol. 1. Clube Internacional do Livro, pp. 23-85.

Raposo, L., 1996. Quartzite bifaces and cleavers in the final Acheulian assemblages of Milharós (Alpiarça, Portugal). In: non-flint stone tools and palaeolithic occupation of the Iberian península. In: Moloney, N., Raposo, L., Santajoa, M. (Eds.), Tempvs Reparatvm, Bar International Series 649, pp. 151-165.

Raposo, L., 2002. Um século de estudos no Paleolítico Médio em Portugal: balanço e perspectivas. Arqueol. História 54, 25-39.

Raposo, L., Cardoso, J.L., 1998. O sítio do Paleolítico Médio da Conceição, Alcochete. Centro de Estudos e Monitorização Ambiental - CEMA, p. 74.

Raposo, L., Carreira, J.R., Salvador, M., 1985. A estação Acheulense final de Milharós Vale do Forno, Alpiarça. Proc. I Reunião do Quaternário Ibérico 2, 41-60.

Roe, D.A., 1968. British lower and middle palaeolithic hand axe groups. Proc. Prehist. Soc. 34, 1-82.

Roquero, E., Silva, P.G., Zazo, C., Goy, J.L., Masana, J., 2015a. Soil evolution indices in fluvial 896 terrace chronosequences of Central Spain (Tagus and Duero fluvia basins). Quat. Int. 376, 101-113.

Roquero, E., Silva, P.G., López Recio, M., Tapias, F., Cunha, P.P., Morín, J., AlcarazCastaño, M., Carrobles, J., Murray, A.S., Buylaert, J.P., 2015b. Geocronología de las terrazas de Pleistoceno Medio y Superior del valle del Tajo en Toledo (España) In: Galve, J.P., Azañon, J.M., Pérez, J.V., Ruano, Peña y P. (Eds.), Una vision global del Cuaternario. El hombre como condicionante de processos geológicos. XIV Reunión Nacional de Cuaternario, Granada, pp. 8-12.

Rosina, P., 2002. Stratigraphie et géomorphologie des terrasses fluviatiles de moyenne Vallée du Tage (Haut Ribatejo, Portugal). In: Cruz, A.R., Oosterbeek, L. (Eds.), Arkeos 13, Territórios, mobilidade e povoamento no Alto-Ribatejo. IV: Contextos macrolíticos. CEIPHAR, pp. 11-52.

Rosina, P., Voinchet, P., Bahain, J., Cristovão, J., Falguères, C., 2014. Dating the onset of Lower Tagus River terrace formation using electron spin resonance. J. Quat. Sci. 29 (2), 153-162.

Roucoux, K.H., de Abreu, L., Shackleton, N.J., Tzedakis, P.C., 2005. The response of NW Iberian vegetation to North Atlantic climate oscillations during the last 65 kyr. Quat. Sci. Rev. 24, 1637-1653.

Roucoux, K., Tzedakis, P. de Abreu, L., Shackleton, N., 2006. Climate and vegetation changes 180,000 to 345,000 years ago recorded in a deep-sea core off Portugal. Earth Planet. Sci. Lett. 249, 307-325.

Rubio-Jara, S., Panera, J., Rodríguez de Tembleque, J., Santonja, M., PérezGonzález, A., 2016. Large flake Acheulean in the middle of Tagus basin (Spain): middle stretch of the river Tagus valley 914 and lower stretches of the rivers Jarama and Manzanares valleys. Quat. Int. http://dx.doi.org/10.1016 j.quaint.2015.12.023.

Salgueiro, E., Voelker, A.H.L., Abreu, L., de Abrantes, F., Meggers, H., Wefer, G., 2010. Temperature and productivity changes off the western Iberian margin during the last 150 ky. Quat. Sci. Rev. 29, 680-695.

Santonja, M., Pérez-González, A., 2010. Mid-pleistocene Acheulian industrial complex in the Iberian Peninsula. Quat. Int. 223-224, 154-161.

Santonja, M., Villa, P., 2006. The Acheulian of western Europe. In: Goren-Inbar, N. Sharon, G. (Eds.), Axe Age: Acheulian Tool-making from Quarry to Discard.
Approaches to Anthropological Archaeology Series. Equinox Publishing, p. 608.

Silva, P.G., Roquero, E., López-Recio, M., Huerta, P., Martínez-Graña, A.M., 2016. Chronology of fluvial terrace sequences for large Atlantic rivers in the Iberian Peninsula (Upper Tagus and Duero drainage basins, Central Spain). Quat. Sci. Rev. http://dx.doi.org/10.1016/j.quascirev.2016.05.027 in press.

Stokes, M., Cunha, P.P., Martins, A.A., 2012. Techniques for analysing river terrace sequences. Geomorphology 165-166, 1-6. http://dx.doi.org/10.1016/ j.geomorph.2012.03.022.

Thomsen, K.J., Murray, A.S., Jain, M., Bøtter-Jensen, L., 2008. Laboratory fading rates of various luminescence signals from feldspar-rich sediment extracts. Radiat. Meas. 43, 1474-1486.

Van der Schriek, T., Passmore, D.G., Rolão, J., Stevenson, A.C., 2007. Estuarine-fluvial floodplain formation in the Holocene Lower Tagus valley (Central Portugal) and implications for Quaternary fluvial system evolution. Quat. Sci. Rev. 26, 2937-2957.

Vepraskas, M.J., Lindbo, D.L., 2012. Redoximorphic features as related to soil hydrology and hydric Soils. Hydropedology 143-172.

Vilanova, S.P., Fonseca, J.F.B.D., 2004. Seismic hazard impact of the lower Tagus valley fault zone (SW Iberia). J. Seismol. 8, 331-345.

Vis, G.-J., 2009. Fluvial and Marine Sedimentation at a Passive Continental Margin. The Late Quaternary Tagus Depositional System. PhD thesis. Vrije University, p. 244.

Vis, G.-J., Kasse, C., Vandenberghe, J., 2008. Late Pleistocene and Holocene palaeogeography of the Lower Tagus Valley (Portugal): effects of relative sea level, valley morphology and sediment supply. Quat. Sci. Rev. 27, 1682-1709.

Vis, G.-J., Kasse, C., Kroon, D., Vandenberghe, J., Jung, S., Lebreiro, S.M., Rodrigues, T., 2016. Time-integrated 3D approach of late Quaternary sediment-depocenter migration in the Tagus depositional systems: from river valley to abyssal plain. Earth-Sci. Rev. 153, 192-211.

White, T.S., Bridgland, D.R., Westaway, R., Straw, A., 2016. Evidence for late middle Pleistocene glaciation of the british margin of the southern north sea. J. Quat. Sci. http://dx.doi.org/10.1002/jqs.2826.

Wintle, A.G., Murray, A.S., 2006. A review of quartz optically stimulated luminescence characteristics and their relevance in single-aliquot regeneration dating protocols. Radiat. Meas. 41, 369-391.

Wright, J.D., 2000. Global climate change in marine stable isotope records. In: Stratton Noler, J., Sowers, J.M., Lettis, W.R. (Eds.), Quaternary Geochronology. Methods and Applications, pp. 427-433.

Yaalon, D.H., 1983. Climate, time and soil development. In: Wilding, L.P., Smeck, N.E., Hall, G.F. (Eds.), Pedogenesis and Soil Taxonomy: I. Concepts and Interactions, Elsevier, Amsterdam, pp. 223-251.

Zbyszewski, G., 1943. La classification du Paléolithic ancien et la chronologie du Quaternaire de Portugal en 1942. Bol. Soc. Geol. Port. 2, 2-3, 111 pp.

Zbyszewski, G., 1946. Étude géologique de la region d'Alpiarça. Comunicações dos Serviços Geológicos de Portugal XXVII, pp. 145-268.

Zbyszewski, G., 1977. Três ossos de vertebrados quaternários. Comunicações dos Serviços Geológicos de Portugal LXII, pp. 191-194.

Zielhofer, C. Recio Espejo, JM., Nunez Granados, M.A., Faust, D. 2009. Durations of soil formation and soil development indices in a Holocene Mediterranean floodplain. Quat. Int. 209, 44-65. 